NBER WORKING PAPER SERIES

CREDIT CRUNCHES AND CREDIT ALLOCATION IN A MODEL OF ENTREPRENEURSHIP

\author{
Marco Bassetto \\ Marco Cagetti \\ Mariacristina De Nardi \\ Working Paper 19296 \\ http://www.nber.org/papers/w19296
NATIONAL BUREAU OF ECONOMIC RESEARCH
1050 Massachusetts Avenue
Cambridge, MA 02138

August 2013

We are grateful to Matthias Doepke, Igor Livshits, Guido Lorenzoni, Nikolai Roussanov, and many seminars participants for helpful comments. The views expressed herein are those of the authors and do not necessarily reflect the views of the National Bureau of Economic Research, the Federal Reserve Bank of Chicago, the Board of Governors, or the Federal Reserve System.

NBER working papers are circulated for discussion and comment purposes. They have not been peerreviewed or been subject to the review by the NBER Board of Directors that accompanies official NBER publications.

(C) 2013 by Marco Bassetto, Marco Cagetti, and Mariacristina De Nardi. All rights reserved. Short sections of text, not to exceed two paragraphs, may be quoted without explicit permission provided that full credit, including (C) notice, is given to the source. 
Credit Crunches and Credit Allocation in a Model of Entrepreneurship

Marco Bassetto, Marco Cagetti, and Mariacristina De Nardi

NBER Working Paper No. 19296

August 2013

JEL No. E2,E21,E23,E6

\begin{abstract}
We study the effects of credit shocks in a model with heterogeneous entrepreneurs, financing constraints, and a realistic firm size distribution. As entrepreneurial firms can grow only slowly and rely heavily on retained earnings to expand the size of their business in this set-up, we show that, by reducing entrepreneurial firm size and earnings, negative shocks have a very persistent effect on real activity. In determining the speed of recovery from an adverse economic shock, the most important factor is the extent to which the shock erodes entrepreneurial wealth.

Marco Bassetto

Research Department

Federal Reserve Bank of Chicago

230 S. LaSalle Street

Chicago, IL 60604

and University College London

mbassetto@frbchi.org

Marco Cagetti

Board of Governors of the Federal Reserve System

Flow of Funds, Mail Stop 97

Washington, DC 20551

Marco.Cagetti@frb.gov

Mariacristina De Nardi

Federal Reserve Bank of Chicago

230 South LaSalle St.

Chicago, IL 60604

and University College London

and also NBER

denardim@nber.org
\end{abstract}




\title{
Credit Crunches and Credit Allocation in a Model of
}

\section{Entrepreneurship*}

\author{
Marco Bassetto ${ }^{\dagger}$ \\ Marco Cagetti ${ }^{\ddagger}$ \\ Mariacristina De Nardi ${ }^{\S}$
}

\begin{abstract}
We study the effects of credit shocks in a model with heterogeneous entrepreneurs, financing constraints, and a realistic firm size distribution. As entrepreneurial firms can grow only slowly and rely heavily on retained earnings to expand the size of their business in this set-up, we show that, by reducing entrepreneurial firm size and earnings, negative shocks have a very persistent effect on real activity. In determining the speed of recovery from an adverse economic shock, the most important factor is the extent to which the shock erodes entrepreneurial wealth.
\end{abstract}

\section{Introduction}

The recent turmoil in financial markets has had deep consequences for the allocation of credit within the economy. Access to credit is particularly important for nascent and growing firms,

${ }^{*}$ We are grateful to Matthias Doepke, Igor Livshits, Guido Lorenzoni, Nikolai Roussanov, and many seminars participants for helpful comments. The views expressed herein are those of the authors and do not necessarily reflect the views of the National Bureau of Economic Research, the Federal Reserve Bank of Chicago, the Board of Governors, or the Federal Reserve System.

${ }^{\dagger}$ Federal Reserve Bank of Chicago and University College London.

${ }^{\ddagger}$ Board of Governors of the Federal Reserve System.

$\S$ Federal Reserve Bank of Chicago, University College London, and NBER. 
for which it is much more difficult to only rely on retained earnings as a source of financing.

In this paper, we study the effect of various types of financial shocks in a model with two nonfinancial sectors: a corporate sector, primarily composed of mature firms, and an entrepreneurial sector, whose leverage is limited by their inability to fully commit to repay their debts. The constraints generate a large, and realistic, dispersion in firm size, and limit the rate at which entrepreneurial firms can grow. We build on the entrepreneurship model of Quadrini [43] and Cagetti and De Nardi [13, 14], and introduce a financial intermediation sector that channels resources from savers to users of capital. Both entrepreneurs and corporate firms require access to intermediated funds. The reliance of entrepreneurs on intermediaries is one of the parameters used in our calibration, and is most associated with matching the ratio of the wealth of entrepreneurs to that of workers. We calibrate directly the reliance of corporate firms on outside funding to match data from the flow of funds.

Our main experiment considers the effects of an increase in the cost of channelling funds through intermediaries, which increases the cost of borrowing and, in general equilibrium, also depresses the rate of return earned by savers. This shock can be the result of either a negative productivity shock in the financial intermediation sector, or the destruction of capital specific to this sector (e.g., the loss in value of mortgage-backed securities). For the parameters that best match our target moments, we find that entrepreneurial firms are affected to a deeper extent than corporate firms. To the extent that entrepreneurial firms tend to be smaller, this is in line with the empirical findings of Gertler and Gilchrist [21]. When intermediation costs return to their steady-state levels, both entrepreneurs and corporate firms stage an initial rebound, but the path to a full recovery is then slow. The wealth accumulation of the entrepreneurs is affected in a very persistent way. Negative credit shocks reduce firm size, and, because entrepreneurial firms can grow only slowly, limit the speed at which firms return to their previous scale when the shocks subside. This slow transition is characterized by more capital misallocation and hence lower output than in steady state.

An increase in intermediation costs also generates an endogenous tightening of borrowing constraints, as entrepreneurial activity becomes less profitable and the outside option of absconding 
part of the capital becomes comparatively more attractive; this channel accounts for about $50 \%$ of the drop in entrepreneurial firm size.

Government policy interacts with the financial disruption. We study two aspects of this interaction. First, the recession initiated by the financial shock creates a shortfall in the government budget. If income taxes are raised to finance this shortfall, they constitute a new, independent drain on entrepreneurial profits, which can be even bigger than the financial shock itself, and leads to an even longer recovery. Second, we analyze the effects of government targeted intervention in the financial markets, that drives a wedge in the cost of funds across different classes of borrowers. Our experiment is closest in spirit to the U.S. Treasury's guarantee of money market mutual funds (and implicitly of the underlying commercial paper): we consider a case in which the government is able to completely and costlessly insulate the corporate sector from the shock. ${ }^{1}$ This guarantee is helpful in reducing the depth of the recession, but it does nothing to improve the recovery, as it concentrates the shock onto the sector that is most vulnerable in the long run.

We contrast the effects of our baseline shock with alternative scenarios, such as a collateral shock, that makes it harder for entrepreneurs to pledge future repayment of debt, similar to Jermann and Quadrini [30], or a traditional TFP shock. We find that the response to these shocks may be quite similar, to the extent that the balance sheet of entrepreneurs is hit in a similar way; the evolution of this balance sheet is the key element that affects the speed of the recovery. In our set-up all these shocks have a very persistent effect on real activity.

\section{Related Works}

Many works incorporate credit-market frictions in macroeconomic models but, rather than studying the direct effect of shocks to these frictions, they focus on how these frictions affect aggregate investment and help generate and amplify business fluctuations. Among the earlier and most influential contributions, Bernanke and Gertler [8] introduce agency problems such as costly

\footnotetext{
${ }^{1}$ The government guarantee of money-market mutual funds was indeed costless ex-post for the United States in the recent crisis; we choose a costless specification not because we believe that it was costless ex-ante, but to show that this guarantee is not a panacea even in the best-case scenario.
} 
state verification in a dynamic general equilibrium set-up, and Kiyotaki and Moore [34] further illustrate the impact of collateral constraints and their interaction with asset prices and firms net worth. In both papers, credit imperfections link investment decisions to the firms' balance sheets and generate a "financial accelerator" that amplifies and propagates shocks to the macroeconomy. The recent financial crisis has given further impetus to this literature, highlighting both the many channels through which credit market imperfections can affect real activity, and the possible effects of government interventions to improve the functioning of credit markets and the flow of funds between borrowers and lenders. For a review of this literature, see Bernanke, Gertler and Gilchrist [9] for earlier contributions and Gertler and Kiyotaki [22], Brunnermeier and Sannikov [10] and Krishnamurthy [36] for more recent ones. Here, we only mention a few of the papers most related to our work.

We model several types of financial frictions. Financial intermediation (and more in general frictions in credit markets) introduce a wedge between the returns to lender and the cost of capital to borrowers, a wedge related to the spread between liquid and easily intermediated securities such as Treasuries and corporate bonds. These credit spreads vary over time and their level and variation have been shown to be empirically correlated to and potentially key to understand output fluctuations (for instance, Gilchrist, Sim and Zakrajsek [23], Christiano, Motto and Rostagno [16], and Adrian and Shin [1]). Their role has been highlighted, among others, by Hall [26], who show that in a simple representative-agent economy credit spreads (including those for households) are powerful determinants of economic activity and can generate fluctuations of the magnitude of those seen in the recent crisis, and by Curdia and Woodford [19], who study how monetary policy rules should respond to shocks to credit spreads. We also find that spreads have a significant impact on aggregate output during a credit crisis; by themselves, spreads have a fairly short-lived effect in our model economy. It is a different source of frictions that propagates the effect of spreads and generates a very persistent drop in output.

Among borrowers, we explicitly distinguish corporate and entrepreneurial firms; the latter potentially face different constraints and have reduced access to financial markets (see e.g. Quadrini [42]). We model credit frictions to entrepreneurs as endogenous borrowing constraints 
arising from imperfect enforceability of debt contracts (as in Kehoe and Levine [31] and Alvarez and Jermann [5]). In this set-up, credit availability to entrepreneurs depends on their balance sheet and their available collateral. This class of models has been shown useful to explain, for instance, firm-size distribution (Akyol and Athreya [6], Monge [41]), firm dynamics (Albuquerque and Hopenhayn [2]), macroeconomic fluctuations (Cooley, Marimon, and Quadrini [17], Jermann and Quadrini [29]), and growth (Buera and Shin [12]). The presence of limited commitment slows the growth of nascent firms and links it to the entrepreneurs' cash flow. It is this channel that propagates the initial financial shock in our model and is responsible for our main results. Our paper is thus also closely related to Khan and Thomas [32], who examine the effect of capital misallocation that result from a collateral requirement shock in a real business cycle model with heterogeneous firms and capital rigidities.

The tightness of the borrowing constraints depends crucially on characteristics of the borrower such as firm size, balance sheet, and personal wealth (Buera [11])). For this reason, we build a model that quantitatively reproduces the high level of dispersion in these variables observed in the data. Our work is thus related to the literature on wealth inequality and its determinants (such as Quadrini and Ríos-Rull [44] and Castaneda, Diaz-Gimenez and Rios-Rull [15]), and especially to the literature that identifies entrepreneurial wealth as a key force generating inequality (Quadrini [42], Cagetti and De Nardi [13]). The interaction between frictions, entrepreneurship, and inequality is crucial to understand the response to macroeconomic shocks (Jermann and Quadrini [30]), the effect of certain government policies (Cagetti and De Nardi [14], Meh [40], Kitao [33]), and asset pricing (Heaton and Lucas [27], Roussanov [45], Covas and Fujita [18]).

\section{The Model}

\subsection{Demographics}

A young person faces a constant probability of aging during each period $\left(1-\pi_{y}\right)$, and an old person faces a constant probability of dying during each period $\left(1-\pi_{o}\right)$. When an old person dies, his offspring enters the model, carrying the assets bequeathed to him by the parent. 


\subsection{Preferences}

The household's flow of utility from consumption is given by $\frac{c_{t}^{1-\sigma}}{1-\sigma}$. The households discount the future at rate $\beta$ and are perfectly altruistic toward their descendants.

\subsection{Technology}

Each person possesses two types of ability, which we take to be exogenous, stochastic, positively autocorrelated, and stochastically independent of each other. Entrepreneurial ability $\left(\theta_{t}\right)$ is the capacity to invest capital and labor more or less productively using one's own production function. Working ability $\left(y_{t}\right)$ is the capacity to produce income out of labor by working for others.

The entrepreneurs can borrow, invest capital, hire labor, and run a technology whose return depends on their own entrepreneurial ability: those with higher ability levels have higher average and marginal returns from capital and labor. When the entrepreneur invests $k_{t}$ production is given by

$$
f\left(k_{t}, n_{t}\right)=\theta_{t}\left(k_{t}^{\gamma}\left(1+n_{t}\right)^{(1-\gamma)}\right)^{\nu}
$$

where $\nu, \gamma \in[0,1]$, and $n$ is hired labor $(n \geq 0)$. We normalize the labor of the entrepreneur to 1. Entrepreneurs thus face decreasing returns from investment, as their managerial skills become gradually stretched over larger and larger projects (as in Lucas [39]). While entrepreneurial ability is exogenously given, the entrepreneurial rate of return from investing in capital is endogenous and is a function of the size of the project that the entrepreneur implements.

There is no within-period uncertainty regarding the returns of the entrepreneurial project. The ability $\theta_{t}$ is observable and known by all at the beginning of the period. We therefore abstract from problems arising from partial observability, costly state verification, and from diversification of entrepreneurial risk.

In addition to entrepreneurs, there is also a non-entrepreneurial sector, represented by a standard Cobb-Douglas production function:

$$
F\left(K_{t}^{c}, L_{t}^{c}\right)=A\left(K_{t}^{c}\right)^{\alpha}\left(L_{t}^{c}\right)^{1-\alpha}
$$


where $K_{t}^{c}$ and $L_{t}^{c}$ are the total capital and labor inputs in the non-entrepreneurial sector and $A$ is a constant. In both sectors, capital depreciates at a rate $\delta$.

\subsection{Credit}

External financing to both entrepreneurs and non-entrepreneurial firms is provided by competitive financial intermediaries. The intermediaries borrow funds from workers (and possibly entrepreneurs, though in equilibrium almost all entrepreneurs will be credit constrained and will invest all their wealth in their own firm).

Intermediation is costly. For each unit of capital, it requires $\phi_{t}$ units of the consumption good as an intermediate input.

Financial intermediaries operate competitively. At any time $t$, they take as given the interest rate required by savers $\left(i_{t}\right)$ and the interest rate paid by borrowers $\left(r_{t}\right)$. Given the technology, an equilibrium with a positive and finite supply of intermediation requires

$$
r_{t}=i_{t}+\phi_{t}
$$

For the non-entrepreneurial sector, we assume that it must finance a given fraction $\xi_{t}$ of its capital through external borrowing. This constraint can be justified by an agency problem between shareholders and managers.

The entrepreneurial demand for borrowed funds arises endogenously in the model. As in Kehoe and Levine [31], entrepreneurs are subject to borrowing constraints that are endogenously determined in equilibrium and stem from the assumptions that contracts are imperfectly enforceable.

In particular, as in Cagetti and De Nardi [13], we assume that the entrepreneurs who borrow either can invest the money and repay their debt at the end of the period or can run away without investing it and be workers for one period. In the latter case, they retain a fraction $f$ of their working capital $k_{t}$ (which includes own assets and borrowed money) and their creditors seize the rest. We assume that labor services are paid at the end of the period, hence entrepreneurs are not constrained in the amount of labor that they hire. 


\subsection{Government and taxation}

The government is infinitely lived. It levies taxes, pays a pension $p_{t}$ to each retiree, provides a certain level $g_{t}$ of public purchases (which do not enter the households' utility function), repays existing debt with interest, and issues new debt. In steady state, tax revenues from income, consumption, and estate taxes are equal to government purchases, pension payments, and interest payments on the debt.

We model progressive taxation of total income as in Cagetti and De Nardi [14], and use their parameter estimates.

Total income taxes paid by each household are given by

$$
T_{t}^{i}\left(Y_{t}\right)=\tau^{i}\left(Y_{t}\right) Y_{t}+\tau_{t}^{s} Y_{t}
$$

where $i$ indicates occupational choice $(e$ or $w) . \tau_{t}^{s}$ represents an additional flat rate that is allowed to adjust to meet the government budget constraint. The government also levies a sales tax on consumption, at rate $\tau^{c}$. Estates larger than a given value $e$ are taxed at rate $\tau^{b}$ on the amount in excess of $e$.

As a first pass, we abstract from the tax implications of corporate finance decisions by assuming that corporate income taxes are zero and that capital gains are taxed as regular income. ${ }^{2}$

\subsection{The corporate firms' problem}

In each period $t$, a corporate firm starts with resources $A_{t}^{C}$, which include undepreciated capital from last period, retained earnings, and last period's equity issuance. The firm uses $A_{t}^{C}$ and new debt (external) financing $B_{t}$ to purchase capital for operation in period $t\left(K_{t}^{C}\right)$, subject to the minimum external finance constraint

$$
B_{t} \geq \xi K_{t}^{C}
$$

Residual internal funds can be invested with financial intermediaries at the rate $i_{t}$.

Since corporate firms will always be owned by savers (workers), their objective function is to maximize the discounted sum of profits, using the interest rate $i_{t}$ as a discount factor.

\footnotetext{
${ }^{2}$ These two assumptions tend to offset each other.
} 
Formally, the problem a firm faces as of period $t$ is described recursively as follows:

$$
\begin{aligned}
J_{t}\left(A_{t}^{C}\right)= & \max _{K_{t}^{C}, L_{t}^{C}, B_{t}, A_{t+1}^{C}} F\left(K_{t}^{C}, L_{t}^{C}\right)+\left(A_{t}^{C}+B_{t}-K_{t}^{C}\right)\left(1+i_{t}\right)-w_{t} L_{t}^{C}-\left(1+r_{t}\right) B_{t}-\delta K_{t}^{C}- \\
& A_{t+1}^{C}+\frac{1}{1+i_{t+1}} J_{t+1}\left(A_{t+1}^{C}\right),
\end{aligned}
$$

subject to

$$
K_{t}^{C} \leq A_{t}^{C}+B_{t}
$$

and (3). In equation (4), $J_{t}$ represents the cum-dividend value of the firm's equity in terms of period- $t$ goods. In period $t$, the firm's profits are given by $F\left(K_{t}^{C}, L_{t}^{C}\right)+\left(A_{t}^{C}+B_{t}-K_{t}^{C}\right)(1+$ $\left.i_{t}\right)-w_{t} L_{t}^{C}-\left(1+r_{t}\right) B_{t}-A_{t+1}^{C}-\delta K_{t}^{C}$. Of these profits, the firm retains $A_{t+1}^{C}$ to finance future operations, and it pays out the rest as dividends (with negative dividends corresponding to new equity issuance).

It is straightforward to verify that the firms' problem is homogeneous of degree 1 in $A_{t}^{C}$. This implies that the size distribution of corporate firms is irrelevant, and we can work with one representative (competitive) firm. It also implies that the firm's value is proportional to its initial internal funds: $J_{t}\left(A_{t}^{C}\right) \equiv \hat{J}_{t} A_{t}^{C}$. Using ${ }^{\wedge}$ to denote the optimal choice rescaled by $A_{t}^{C}$ and denoting by $\omega_{1 t}$ and $\omega_{2 t}$ the Lagrange multipliers on (5) and (3) respectively, the first-order conditions that will hold if the corporate sector is active yield:

$$
\begin{gathered}
F_{K}\left(\hat{K}_{t}^{C}, \hat{L}_{t}^{C}\right)-\delta=1+i_{t}+\omega_{1 t}+\xi \omega_{2 t}, \\
F_{L}\left(\hat{K}_{t}^{C}, \hat{L}_{t}^{C}\right)=w_{t} \\
r_{t}-i_{t}=\omega_{1 t}+\omega_{2 t}
\end{gathered}
$$

and

$$
1=\frac{\hat{J}_{t+1}}{1+i_{t+1}}
$$

For $t>0$, the envelope condition yields

$$
\hat{J}_{t}=1+i_{t}+\omega_{1 t}
$$

From these equations, for period $t>1$ we obtain

$$
F_{K}\left(\hat{K}_{t}^{C}, \hat{L}_{t}^{C}\right)=\delta+(1-\xi) i_{t}+\xi r_{t} .
$$


In the initial period, the internal funds of the corporate sector $\left(A_{1}^{C}\right)$ are exogenously given. Depending on its value and factor prices, the corporate firms' optimization problem yields

$$
F_{K}\left(\hat{K}_{1}^{C}, \hat{L}_{1}^{C}\right)-\delta \begin{cases}=r_{1} & \text { if } \hat{K}_{1}>\frac{1}{1-\xi} \\ \in\left[(1-\xi) i_{1}+\xi r_{1}, r_{1}\right] & \text { if } \hat{K}_{1}=\frac{1}{1-\xi} \\ =(1-\xi) i_{1}+\xi r_{1} & \text { if } \hat{K}_{1}<\frac{1}{1-\xi} .\end{cases}
$$

Given our assumptions, the timing of dividend payments does not matter. Whether dividends are kept by the firm as retained earnings, or distributed and invested by firm owners, they yield the same rate of return $i_{t}$. For this reason, we assume that the corporate sector has enough retained earnings so that $\hat{K}_{1}<1 /(1-\xi)$ even when faced with the unexpected shocks described below. ${ }^{3}$ In this case, equation (9) coincides with equation (8), and we obtain $\hat{J}_{1}=1+i_{1}$. A corollary of this result is that firm owners will not have unexpected capital gains (or losses) when the shock occurs. This allows us to only keep track of their total assets invested with third parties, without distinguishing between firm stock, funds invested with intermediaries, and government debt.

\subsection{Households}

Each young individual starts the period with assets $a_{t}$, entrepreneurial ability $\theta_{t}$, and worker ability $y_{t}$, and chooses whether to be an entrepreneur or a worker during the current period.

An old entrepreneur that is still able to run a business can decide to keep the activity going or retire, while a retiree cannot start a new entrepreneurial activity.

\section{The young's problem}

The value function of a young person is

$$
V_{t}\left(a_{t}, y_{t}, \theta_{t}\right)=\max \left\{V_{t}^{e}\left(a_{t}, y_{t}, \theta_{t}\right), V_{t}^{w}\left(a_{t}, y_{t}, \theta_{t}\right)\right\}
$$

\footnotetext{
${ }^{3}$ In a stochastic model, corporate firms would find it optimal to accumulate financial asset and to ensure that the condition above is satisfied, since a shortfall in resources would require costly debt financing.
} 
where $V_{t}^{e}\left(a_{t}, y_{t}, \theta_{t}\right)$ is the value function of a young individual who manages an entrepreneurial activity during the current period. The term $V_{t}^{w}\left(a_{t}, y_{t}, \theta_{t}\right)$ is the value function if he chooses to be a worker during the current period.

The young entrepreneur's problem can be written as

$$
V_{t}^{e}\left(a_{t}, y_{t}, \theta_{t}\right)=\max _{c_{t}, k_{t}, n_{t}, a_{t+1}}\left\{u\left(c_{t}\right)+\beta \pi_{y} E_{t} V_{t+1}\left(a_{t+1}, y_{t+1}, \theta_{t+1}\right)+\beta\left(1-\pi_{y}\right) E_{t} W_{t+1}\left(a_{t+1}, \theta_{t+1}\right)\right\}
$$

subject to

$$
\begin{gathered}
Y_{t}^{e}=\theta\left(k_{t}^{\gamma}\left(1+n_{t}\right)^{(1-\gamma)}\right)^{\nu}-\delta k_{t}-\left(k_{t}-a_{t}\right)\left(r_{t} I_{k_{t}>a_{t}}+i_{t} I_{k_{t}<a_{t}}\right)-w_{t} n_{t} \\
a_{t+1}=Y_{t}^{e}-T_{t}^{e}\left(Y_{t}^{e}\right)+a_{t}-\left(1+\tau_{t}^{c}\right) c_{t} \\
u\left(c_{t}\right)+\beta \pi_{y} E_{t} V_{t+1}\left(a_{t+1}, y_{t+1}, \theta_{t+1}\right)+\beta\left(1-\pi_{y}\right) E_{t} W_{t+1}\left(a_{t+1}, \theta_{t+1}\right) \geq V_{t}^{w}\left(f \cdot k_{t}, y_{t}, \theta_{t}\right) \\
a_{t} \geq 0 \\
n_{t} \geq 0 \\
k_{t} \geq 0 .
\end{gathered}
$$

The term $Y_{t}^{e}$ represents the entrepreneur's total profits. The expected value of the value function is taken with respect to $\left(y_{t+1}, \theta_{t+1}\right)$, conditional on $\left(y_{t}, \theta_{t}\right)$. Eq. (14) determines the maximum amount that an entrepreneur with given state variables can borrow. The term $W_{t}\left(a_{t+1}, \theta_{t+1}\right)$ is the value function of the old entrepreneur at the beginning of the period, before deciding whether to stay in business or retire. We have

$$
V_{t}^{w}\left(a_{t}, y_{t}, \theta_{t}\right)=\max _{c_{t}, a_{t+1}}\left\{u\left(c_{t}\right)+\beta \pi_{y} E_{t} V_{t+1}\left(a_{t+1}, y_{t+1}, \theta_{t+1}\right)+\beta\left(1-\pi_{y}\right) W_{t+1}^{r}\left(a_{t+1}\right)\right\}
$$

subject to eq. (15) and

$$
\begin{gathered}
Y_{t}^{w}=w_{t} y_{t}+i_{t} a_{t} \\
a_{t+1}=\left(1+i_{t}\right) a_{t}-T_{t}^{w}\left(Y_{t}^{w}\right)-\left(1+\tau_{t}^{c}\right) c_{t},
\end{gathered}
$$

where $w_{t}$ is the equilibrium wage rate. 


\section{The old's problem}

Since the old entrepreneur can choose to continue the entrepreneurial activity or retire, his state variables are his current assets $a_{t}$ and his entrepreneurial ability level $\theta_{t} .{ }^{4}$ His value function is given by

$$
W_{t}\left(a_{t}, \theta_{t}\right)=\max \left\{W_{t}^{e}\left(a_{t}, \theta_{t}\right), W_{t}^{r}\left(a_{t}\right)\right\},
$$

where $W_{t}^{e}\left(a_{t}, \theta_{t}\right)$ is the value function for the old entrepreneur who stays in business, and $W_{t}^{r}\left(a_{t}\right)$ is the value function of the old retired person. Define the inherited assets, net of estate taxes, as $a_{t+1}^{n}=a_{t+1}-\tau_{t+1}^{b} \cdot \max \left(0, a_{t+1}-e_{t+1}\right)$. We have

$$
W_{t}^{e}\left(a_{t}, \theta_{t}\right)=\max _{c_{t}, k_{t}, n_{t}, a_{t+1}}\left\{u\left(c_{t}\right)+\beta \pi_{o} E_{t} W_{t+1}\left(a_{t+1}, \theta_{t+1}\right)+\beta\left(1-\pi_{o}\right) E_{t} V_{t+1}\left(a_{t+1}^{n}, y_{t+1}, \theta_{t+1}\right)\right\}
$$

subject to eq. (12), eq. (13), eq. (15), eq. (16), eq. (17) and

$$
u\left(c_{t}\right)+\beta \pi_{o} E_{t} W_{t+1}\left(a_{t+1}, \theta_{t+1}\right)+\beta\left(1-\pi_{o}\right) E_{t} V_{t+1}\left(a_{t+1}^{n}, y_{t+1}, \theta_{t+1}\right) \geq W_{t}^{r}\left(f \cdot k_{t}\right) .
$$

The child of an entrepreneur is born with ability level $\left(\theta_{t+1}, y_{t+1}\right)$. The expected value of the child's value function with respect to $y_{t+1}$ is computed using the invariant distribution of $y_{t}$, while the one with respect to $\theta_{t+1}$ is conditional on the parent's $\theta_{t}$ and evolves according to the same Markov process that each person faces for $\theta_{t}$ while alive. This is justified by the assumption that the child of an entrepreneur inherits the parent's firm.

A retired person (who is not an entrepreneur) receives pensions and social security payments $\left(p_{t}\right)$ and consumes his assets. His value function is

$$
W_{t}^{r}\left(a_{t}\right)=\max _{c_{t}, a_{t+1}}\left\{u\left(c_{t}\right)+\beta \pi_{o} W_{t+1}^{r}\left(a_{t+1}\right)+\beta\left(1-\pi_{o}\right) E_{t} V_{t+1}\left(a_{t+1}^{n}, y_{t+1}, \theta_{t+1}\right)\right\}
$$

subject to eq. (15) and

$$
a_{t+1}=\left(1+i_{t}\right) a_{t}+p_{t}-T_{t}^{w}\left(p_{t}+i_{t} a_{t}\right)-\left(1+\tau_{t}^{c}\right) c_{t}
$$

The expected value of the child's value function is taken with respect to the invariant distribution of $y_{t}$ and $\theta_{t}$.

\footnotetext{
${ }^{4}$ We assume that the option of continuing is only open to entrepreneurs that have not lost their entrepreneurial skill. We rule out the possibility that an old person with $\theta_{t}=0$ chooses not to retire to preserve the future option of starting a new business should $\theta_{t}$ revert to the higher level.
} 


\subsection{Equilibrium definition}

Let $x_{t}=\left(a_{t}, y_{t}, \theta_{t}, z_{t}\right)$ be the state vector, where $z$ distinguishes young workers, young entrepreneurs, old entrepreneurs, and old retired. From the decision rules that solve the maximization problem and the exogenous Markov process for income and entrepreneurial ability, we can derive a transition function $M_{t}\left(x_{t}, \cdot\right)$, which provides the probability distribution of $x_{t+1}$ (the state next period) conditional on the current state $x_{t}$.

An equilibrium is given by the following elements at any time $t$ :

interest rates $r_{t}, i_{t}$, a wage rate $w_{t}$,

taxes $\left(T^{w}(),. T^{e}(),. \tau^{c}, \tau_{t}^{s}, \tau^{b}\right)$, a bequest exemption level $e$, and social security payments $p_{t}$,

allocations $c_{t}(x)$, and $a_{t}(x)$, occupational choices,

entrepreneurial labor hiring $n_{t}(x)$, and investments $k_{t}(x)$,

and a distribution of people over the state variables $x_{t}: m_{t}(x)$,

such that, given $i_{t}, r_{t}, w_{t}$, and government taxes and transfer schedules:

- The functions $c_{t}, a_{t}, n_{t}$ and $k_{t}$ solve the maximization problems described above.

- The amounts of labor and capital employed by the corporate sector satisfy (6) and (8).

- Financial intermediaries break even, that is, equation (2) holds.

- The value of corporate firms is given by (7).

- The labor market clears, that is, the total labor supplied by the workers equals the total labor employed in the non-entrepreneurial sector and total labor hired by the entrepreneurs.

- The capital markets clear. Total household savings (inclusive of capital owned indirectly through the stock of corporate firms) are equal to the capital employed for production by the corporate sector and by the entrepreneurs, government debt, and the capital used by financial intermediaries as an intermediate input.

- The government budget constraint balances in present value: total taxes collected plus new debt issues equal government purchases, transfers, and repayment of previously issued 
government debt (with interest):

$$
\int\left(T^{x}\left(Y_{x}\right)+\tau^{c} c(x)+I_{o}(x) \tau^{b}\left(1-\pi_{o}\right) \cdot \max \left(0, a_{t+1}\left(x_{t}\right)-e_{t}\right)\right) d m_{t}(x)=p_{t} \pi_{r}+g_{t}+\left(1+i_{t}\right) D_{t}-D_{t+1} .
$$

The integral is over all of the population, $I_{o}$ is an indicator function that is equal to one if the person is old and zero otherwise, and $\pi_{r}$ is the fraction of retired people in the population. In steady state $D_{t}=\bar{D}$.

- The government present-value budget constraint holds, i.e.,

$$
\lim _{t \rightarrow \infty} D_{t} \prod_{s=2}^{t-1} \frac{1}{1+i_{s}}=0
$$

- The distribution of people $m_{t}$ is induced by the transition matrix of the system as follows

$$
m_{t+1}^{\prime}=M_{t}\left(x_{t},\right)^{\prime} m(t)^{\prime}
$$

In steady state $m_{t}=m^{*}$ is the invariant distribution for the economy and debt, prices, and government policies are constant and the individual's decision rules are time-independent.

\section{Calibration}

In this section, we describe the parameters taken from the literature or estimated outside of the model (table 1), and the moments we use to calibrate the remaining parameters (tables 2 and $3)$.

\subsection{Non-calibrated parameters}

The coefficient of relative risk aversion $\sigma$, the capital share in the non-entrepreneurial CobbDouglas production function $\alpha$, and the depreciation rate $\delta$ are set to values commonly used in the literature (for instance, respectively, Attanasio et al. [7], Stokey and Rebelo [46], and Gollin [24]).

The probabilities of aging and of dying are such that the average length of working life is 45 years and that of retirement is 11 years. 


\begin{tabular}{ccc} 
Parameter & Value & Source $(\mathrm{s})$ \\
\hline Preferences, technology, and demographics & \\
\hline$\sigma$ & 1.5 & Attanasio et al. $[7]$ \\
$\delta$ & .06 & Stokey and Rebelo $[46]$ \\
$\alpha$ & .33 & Gollin $[24]$ \\
$A$ & 1 & normalization \\
$\phi$ & .015 & Baa-Treasury spread \\
$\xi$ & .33 & Flow of funds \\
$\pi_{y}$ & .98 & average working life: 45 years \\
$\pi_{o}$ & .91 & average retirement life: 11 years \\
\hline
\end{tabular}

Labor income process and social security payments

y, $P_{y} \quad$ see appendix in Cagetti and De Nardi [14] Huggett [28], Lillard et al. [38]

$p \quad 40 \%$ average yearly income $\quad$ Kotlikoff et al. [35]

Public expenditure, government debt, and taxes

\begin{tabular}{ccc}
\hline$g$ & $18.7 \%$ GDP & NIPA \\
$D$ & see text & Altig et al. [3] \\
$\tau_{c}$ & $11 \%$ & Altig et al. [3] \\
$b_{w}$ & .32 & Cagetti and De Nardi $[14]$ \\
$b_{e}$ & .26 & Cagetti and De Nardi $[14]$ \\
$s_{w}$ & .22 & Cagetti and De Nardi $[14]$ \\
$p_{w}$ & .76 & Cagetti and De Nardi $[14]$ \\
$p_{e}$ & 1.4 & Cagetti and De Nardi $[14]$ \\
$s_{e}$ & .42 & Cagetti and De Nardi $[14]$ \\
\hline
\end{tabular}

Table 1: Fixed parameters and their sources. 
We assume that the logarithm of the workers' income is an $\mathrm{AR}(1)$ process and approximate it as a 5 point Markov chain using Tauchen and Hussey's [47] method. The autocorrelation coefficient and the variance of the error term for the AR(1) process are chosen to obtain a correlation coefficient of .95 (among others, Lillard et al. [38]) and a Gini coefficient for earnings of .38 (Huggett [28] and De Nardi [20]).

The social security replacement rate is $40 \%$ of average gross income (see Kotlikoff, Smetters and Walliser [35]). The steady-state ratio of government spending to GDP is set to $18.7 \%$, and the tax rate on consumption is 11\%. All of these parameter choices are discussed in Cagetti and De Nardi [14].

We set the steady-state financial intermediation cost to obtain a $1.5 \%$ spread between the interest rate paid by borrowers and that received by lenders. This is calibrated to the historical average of the spread between Baa-rated companies and Treasuries. In our model, both public and private debt is risk free, and the spread is entirely due to the special liquidity role of Treasuries, that are assumed not to require any intermediation. For this reason, we choose to match our private borrowing rate to an empirical counterpart that features low default risk but is also unlikely to carry any liquidity premium (see Krishnamurthy-Vissing Jorgensen [37] for more discussion). As a comparison with other securities, the average spread between AAArated corporate bonds and Treasuries is about $1.25 \%$ and that between BBB-rated bonds and Treasuries is about $2.2 \%$.

The parameter $\xi$, the constraint on debt financing, is the average ratio of total corporate debt to the value of corporate tangible assets, a ratio equal to about .34 in the Flow of Funds Accounts. Corporate debt includes commercial paper, corporate bonds, mortgages, and other loans; tangible assets include equipment and software (at replacement cost), structures (at market value), and inventories. The ratio has generally been increasing since the beginning of the data in 1950, from below .25 during the 1950's to values near or above .5 in recent years. This ratio jumped to .58 immediately after the financial crisis, as the crash in commercial real estate prices sharply reduced the value of tangible assets, but since 2009 the ratio has been trending down towards pre-recession norms. 
We use Gouveia and Strauss's [25] parametrization of the average tax rate:

$$
\tau^{i}\left(Y_{t}\right)=b^{i}-b^{i}\left(s^{i} Y_{t}^{p^{i}}+1\right)^{-\frac{1}{p^{i}}}
$$

We estimate the relation separately for entrepreneurs and workers, using nonlinear least on 1989 PSID data. Our measure of total monetary income includes all forms of labor income, capital income, transfers, and income from entrepreneurial activities. Total federal taxes paid is the variable computed in the PSID (in our case, V18862 in the 1990 file). The dependent variable in the regression, average tax rate, is the ratio of (PSID-estimated) federal taxes paid to total monetary income. To obtain a representative sample, we exclude the poverty and Latino samples. To obtain the appropriate tax rate for our model (in which the lowest income level is positive), we also drop all observations with income smaller than $\$ 1,000$ or negative taxes paid. We define as entrepreneurs those who declare themselves to be self-employed and own or have a financial interest in a business activity. The resulting sample of entrepreneurs has very similar characteristics to those from the SCF. Our estimates would be very similar if we were to assume a somewhat smaller or larger cutoff for the amount of business income received during the period.

For the other parameters, we take a ratio of government expenditures to GDP of 18.7\% (NIPA data), a consumption tax of about 11\% (Altig et al. [4]), and a level of government debt that, given the equilibrium interest rate, yields an average ratio of total interest payments to GDP of $3 \%$ (Altig et al. [3]).

\subsection{Calibration targets}

In previous work (Cagetti and De Nardi [14]), we have discussed the relevant empirical counterpart to concept of entrepreneur in this model. Our entrepreneurs are the self-employed business owners that actively manage their own firm(s). We identify them in the Survey of Consumer Finances $(\mathrm{SCF})$ with those that declare that they are self-employed, that they own a business, and that they actively manage it.

We assume that the worker's income ability process is independent from the entrepreneurial ability process (Cagetti and De Nardi [13] discuss how the results change with a different correlation coefficient between the two processes). We consider only two values of entrepreneurial 


\begin{tabular}{lcc}
\hline $\begin{array}{l}\text { Target } \\
\text { Moment }\end{array}$ & Target & Model \\
\hline Capital-output ratio & $2.9-3.0$ & 3.0 \\
Percentage of Entrepreneurs & $7.5-7.6$ & 7.7 \\
Percentage of Exiting Entrepreneurs & $22-24$ & 22.4 \\
Percentage of Workers Entering Entrepreneurship & $2.0-3.0$ & 2.4 \\
Median Net Worth of Entrepreneurs to Workers & $5.3-6.5$ & 6.2 \\
Percentage of People at Zero Wealth & $7-13$ & 11.9 \\
Percentage of Entrepreneurs Hiring on the Labor Market & $57.4-64.6$ & 58.8 \\
Revenue from Estate and Gift Taxes (as \% of output) & $0.2-0.3$ & 0.27 \\
Percentage of Estates Paying Estate Taxes & $1.5-2.0$ & 1.9 \\
\hline
\end{tabular}

Table 2: Target values.

\begin{tabular}{cc}
\hline $\begin{array}{c}\text { Calibrated } \\
\text { Parameter }\end{array}$ & Value \\
\hline$\beta$ & .91 \\
$\theta$ & $\{0,1.16\}$ \\
$P_{\theta}$ & see text \\
$\nu$ & .88 \\
$\gamma$ & .80 \\
$f$ & $75 \%$ \\
$\tau_{b}$ & $16 \%$ \\
$e$ & 120 \\
\hline
\end{tabular}

Table 3: Calibrated parameters. 
ability: zero (no entrepreneurial ability) and a positive number. This implies that $P_{\theta}$ is a twoby-two matrix. Since its rows have to sum to one, this gives us two parameters to calibrate. We also have to choose values for $\nu$, the degree of decreasing returns to scale to entrepreneurial ability, $\gamma$, the share of income going to entrepreneurial working capital, $f$, the fraction of working capital the entrepreneur can keep in case he defaults, the estate tax rate, and its corresponding exemption level.

In total, we calibrate nine parameters. We use the first seven parameters to target the following moments: the capital-output ratio, the fraction of entrepreneurs in the population, the fraction of entrepreneurs exiting entrepreneurship during each period, the fraction of workers becoming entrepreneurs during each period, ${ }^{5}$ the ratio of median net worth of entrepreneurs to that of workers, the fraction of people with zero wealth, and the fraction of entrepreneurs hiring workers on the labor market. We choose the other two parameters to match the revenue from estate and gift taxes and the fraction of the estates that pay estate taxes. Table 2 reports the target values from the data and the values generated from our model; Table 3 reports the parameter values used in our calibration.

For the capital output ratio, we use the Federal Reserve Board Flow of Funds Accounts. We define capital as tangible assets excluding consumer durables and excluding federal and state and local governments assets. The measure thus includes equipment and software, structures, both residential and nonresidential, and inventories. Equipment and software is measured at replacement cost; structures are measured at market value (except nonresidential structures owned by the financial sector, for which market value information is not recorded). With this definition, the ratio for the available years (1960-2009) is 2.96. Excluding the data after year 2000, which have experienced first a large increase and then a boost in house values, the ratio is slightly smaller, about 2.89 .

\footnotetext{
${ }^{5}$ Both in the model and in the data, entry and exit rates refer only to people that were in the model (or survey) in both periods and transitioned from one occupation to the other; they do not include people that die while running an enterprise, nor people that start their enterprise at the beginning of their economic life. For this reason, entry, exit, and the steady-state fraction of entrepreneurs are not linked by the identity that would hold in an economy with infinitely-lived agents.
} 
The fraction of entrepreneurs in the population, the probability of entering and exiting entrepreneurship ${ }^{6}$, the ratio of the median wealth of an entrepreneur to that of a non-entrepreneur and the fraction of entrepreneurs hiring workers are computed from the 1989 Survey of Consumer Finances (other waves gives similar results). We compute the transition matrix between entrepreneurship and non-entrepreneurship by looking at households who are present in two consecutive surveys.

The fraction of the population at zero wealth, also computed from the SCF, is somewhat sensitive to the exact cutoff point (whether exactly zero, or some positive but small amount such as $\$ 100)$. This fraction varies from roughly $7 \%$ to $13 \%$. The percentage of entrepreneurs hiring workers (besides themselves and, possibly, their spouse) is also computed from the SCF.

We do not use the statutory exemption and tax schedule to model the estate tax. As explained in Cagetti and De Nardi [14] and in the references therein, these can differ substantially from the statutory one. We thus calibrate the exemption level and the (flat) tax rate above the exemption to match the percentage of estates that pay an estate tax $(2 \%)$ and the total amount of revenues of estate and gift taxes (about .2-.3\% of GDP).

\section{A Discussion of the Steady State, the Fit of the Model and its Mechanisms}

As we have shown in our previous work, our model of entrepreneurship, although simple, matches very well the wealth distributions of both entrepreneurs and workers. In presence of borrowing constraints, this is very important to determine the response to financial shocks for both the whole distribution of entrepreneurs and for the important macroeconomic aggregates. Figures 1 and 2 compare the distribution of net worth for workers and entrepreneurs generated by the

\footnotetext{
${ }^{6}$ Both in the model and in the data, entry and exit rates refer only to people who were in the model (or survey) in both periods and transitioned from one occupation to the other; they do not include people who die while running an enterprise, nor people who start their enterprise at the beginning of their economic life. For this reason, entry, exit, and the steady-state fraction of entrepreneurs are not linked by the identity that would hold in an economy with infinitely lived agents.
} 


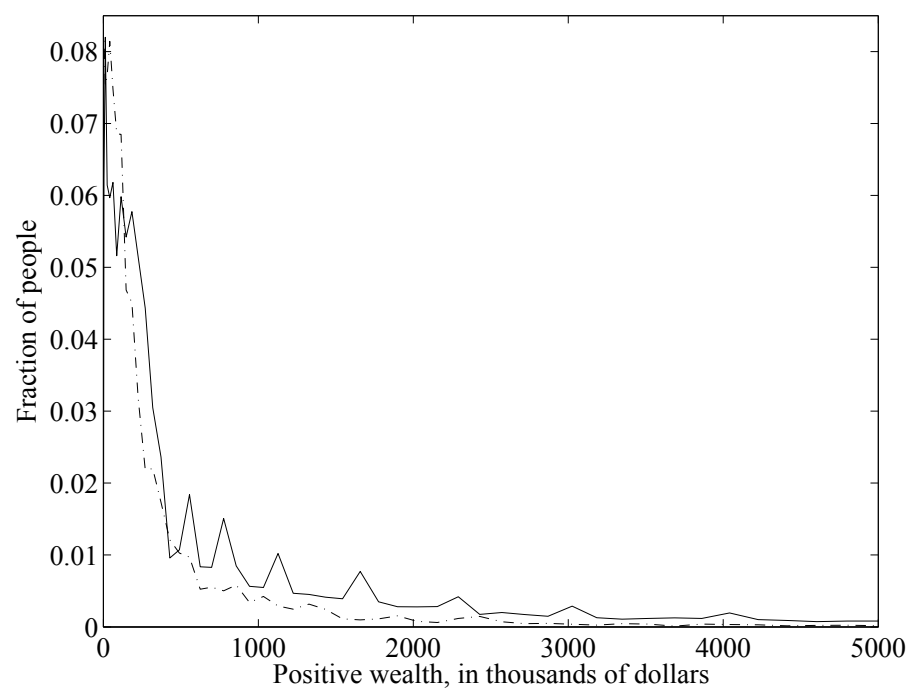

Figure 1: Distribution of wealth, conditional on wealth being positive, for the whole population. Dash-dot line: data; solid line: model.

model and in the actual SCF data and confirms that the model generates the long upper tail of the wealth distribution that is observed in the data for the whole population, and also the large wealth holdings concentrated in the hands of a few entrepreneurs.

In our calibration the entrepreneurial sector employs about $57 \%$ of the capital, a little over the one reported by the Small Business Administration (which is about 50\%). ${ }^{7}$ It also employs $33 \%$ of the efficiency units of labor in the economy; in the data, the Small Business Administration that they employ almost $50 \%$ of the workers in the economy; in the data larger (corporate) firms tend to pay more, which helps in closing this gap. Table 4 displays the distribution of labor hiring by entrepreneurial firms. The first line is computed from the 2007 SCF data, which is the last survey year before the crisis (the numbers from previous years are very similar). The question asked in the SCF is how many workers the entrepreneurs hire in their firm (we exclude the entrepreneur and his or her spouse). To compare it with the model, we assume that the average employee of the entrepreneurial firm (up to the 95\% quantile) lies at either the 33rd

\footnotetext{
${ }^{7}$ The figures from the Small Business Administration refer to independent businesses having fewer than 500 employees. This definition is a reasonable, but not perfect match with our entrepreneurs.
} 


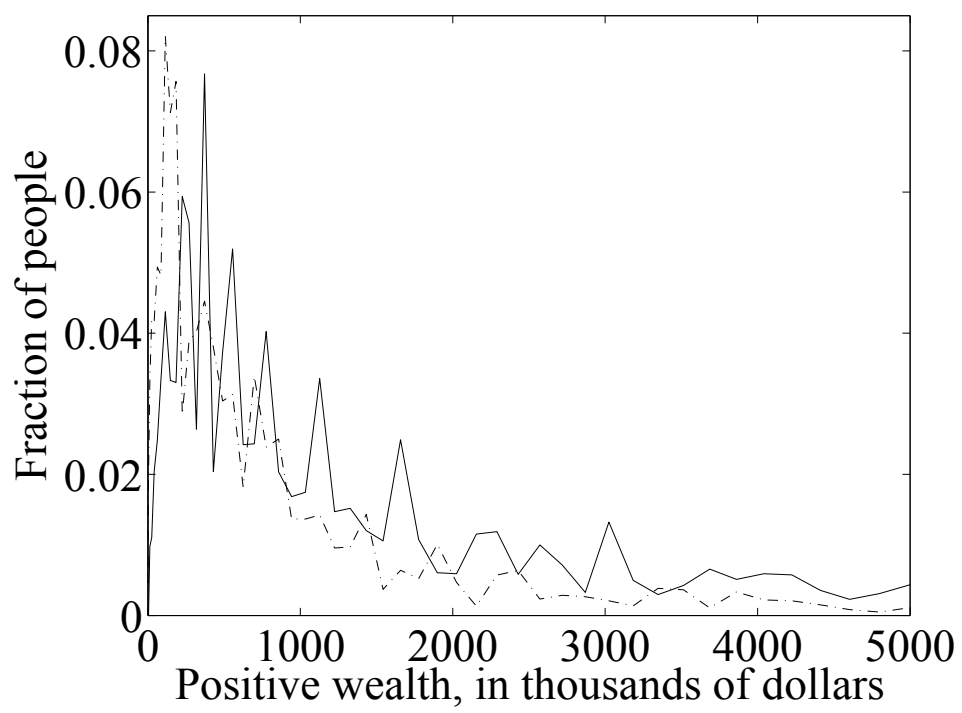

Figure 2: Distribution of wealth, conditional on wealth being positive, for the entrepreneurs. Dash-dot line: data; solid line: model.

\begin{tabular}{lccccc}
\hline Labor hiring & $25 \%$ & $50 \%$ & $75 \%$ & $90 \%$ & $95 \%$ \\
\hline 2007 SCF data, number of workers & 0 & 1 & 5 & 18 & 49 \\
\hline Model, number of 33rd percentile workers & 0 & 0.6 & 5.0 & 15 & 27 \\
\hline Model, number of median workers & 0 & 0.4 & 2.9 & 8.8 & 16 \\
\hline
\end{tabular}

Table 4: Workers hiring in the SCF data and in the model.

quantile (second line) or the median of the efficiency distribution (third line) and that it works full time. Given that part the employees in the SCF data will be part time, we conclude that the distribution of hiring by entrepreneurial firms in the model matches the one in the data reasonably well.

To better understand the workings of the model, the left hand side panel of Figure 3 reports maximum investment as a function of one's net worth (expressed in terms of multiples of average income) for a young entrepreneur of median worker ability. Until the entrepreneur owns enough assets, he keeps being a worker and does not enter entrepreneurship. For this reason, both investment and leverage are reported as being zero until the entry point. The solid line refers to 
the benchmark economy, while the crossed line refers to an economy in which the enforcement frictions become tighter $(f=0.80$, up from 0.75). The picture shows that tighter borrowing constraints do not shift the amount of resources that one needs to hold to find it profitable to enter entrepreneurship: the tightening of the constraint discourages entry, but at the same time it induces a lower interest rate, which has a countervailing effect. Even though entry occurs at similar wealth levels, tighter borrowing constraints result in smaller investment and leverage and slow business growth. In the aggregate economy, slower-growing firms result in less capital accumulation and less inequality. The capital-output ratio in steady state drops from 3.0 to 2.9, the Gini coeeficient drops from 0.81 to 0.79 , and the share of net worth held by the richest $1 \%$ drops from $28.4 \%$ to $26.4 \%$.
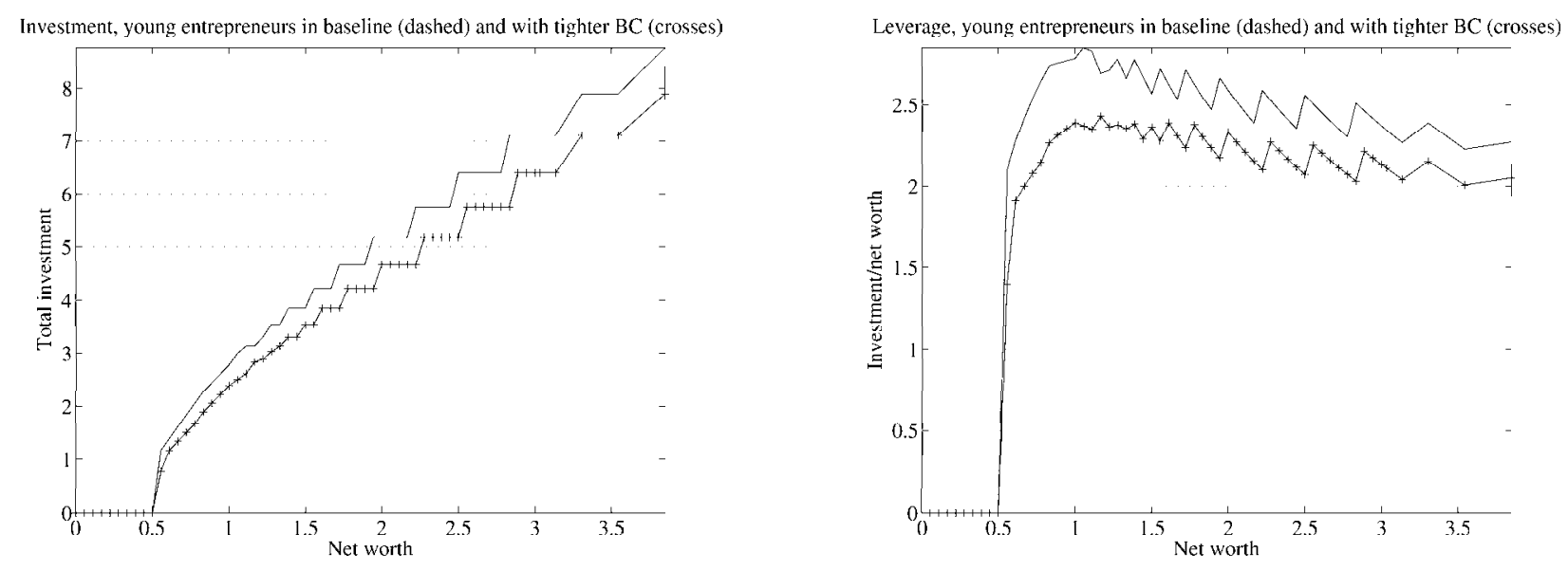

Figure 3: Left panel: Investment as a function of one's net worth (in multiples of average income) and workers' ability. Right panel: Borrowing as a function of one's assets. baseline model. Right panel: baseline model and model with tighter borrowing constraints 
In the data, entrepreneurs are much richer than workers, and their saving rate does not quickly decline with wealth. To match these facts, the calibration implies borrowing limits that are tight compared to the optimal firm size, hence the growth process of entrepreneurial firms is slow. This plays an important role for the response of the economy to various shocks, to which we now turn.

\section{Computing Transitions: The shocks and their effects}

Throughout the experiments below, a shock hits the economy unexpectedly in year 2 and lasts for 3 years. After year 4, the exogenous parameters return to their steady state level.

The sequence of events within a period is as follows:

- Idiosyncratic shocks and the unexpected aggregate shock are realized. All agents have perfect foresight about aggregates from this period onwards.

- Capital markets open; entering entrepreneurs liquidate their positions in corporate stock and government debt to invest in their own business, and borrow from intermediaries; workers and retirees (both from the previous period as well as exiting entrepreneurs) absorb these positions and lend to the intermediaries. Corporate firms raise funds from intermediaries according to their constraint (3) and deposit any internal funds in excess. ${ }^{8}$

- Corporate firms and entrepreneurs hire workers and production takes place.

- Wages, taxes, and dividends are paid, loans are repaid, and the government issues new debt.

- Households consume and government spending occurs.

\footnotetext{
${ }^{8}$ We assume that the interest rate on government debt is also reset at this stage, even though debt is issued at the end of the previous period. Results are very similar if we assume that the rate of return on government debt is predetermined; in this case, the government would not benefit from the drop in $i_{2}$ and taxes would have to be slightly higher to balance the budget.
} 
For each experiment, we isolate the effects of taxes and interest-rate changes by proceeding as follows. First, we keep lending rates, taxes, and government debt fixed at the initial steady state level, and we let government expenditure adjust to balance the government budget constraint. Second, we let lending rates clear the capital market in a closed economy, while we still keep taxes and government debt fixed at the initial steady state level, with government spending acting again as a residual. Finally, we consider an experiment where government spending is fixed, and both taxes and interest rates adjust. In particular, we increase the proportional component of the tax schedule $\left(\tau_{t}^{s}\right)$ after the end of the financial shock, in years 5 through 13 , to balance the present-value budget constraint of the government. We are interested in this comparison to understand the way in which taxes affect entrepreneurial incentives; a meaningful welfare comparison between cuts in government spending and increases in tax rates is not possible in our model, since by assumption government spending is wasted.

\subsection{Negative technology shock in the intermediation sector.}

We consider the effect of a shock that unexpectedly increases $\phi$ from $1.5 \%$ to $3.5 \%$ for three years. ${ }^{9}$

This is a way of capturing either of two alternative shocks:

- More monitoring is necessary to ensure loan performance due to the financial turmoil.

- $\phi$ stands in as payments to a factor that is fixed in the short run and that is temporarily depleted. As an example, suppose that banks face capital requirements and that some initial losses wipe some of the capital out, constraining the banks' ability to offer additional intermediation services. In this case, the increase in $\phi$ would reflect the additional reward for the scarcer banking capital. ${ }^{10}$

\footnotetext{
${ }^{9}$ For a comparison, the spread between Baa corporate bonds and Treasuries jumped to more than $5 \%$ after the recent crisis, and decreased only gradually over the course of 2009.

${ }^{10}$ To spell out completely this story, we should explain what prevents capital from immediately flowing back into the banking sector.
} 

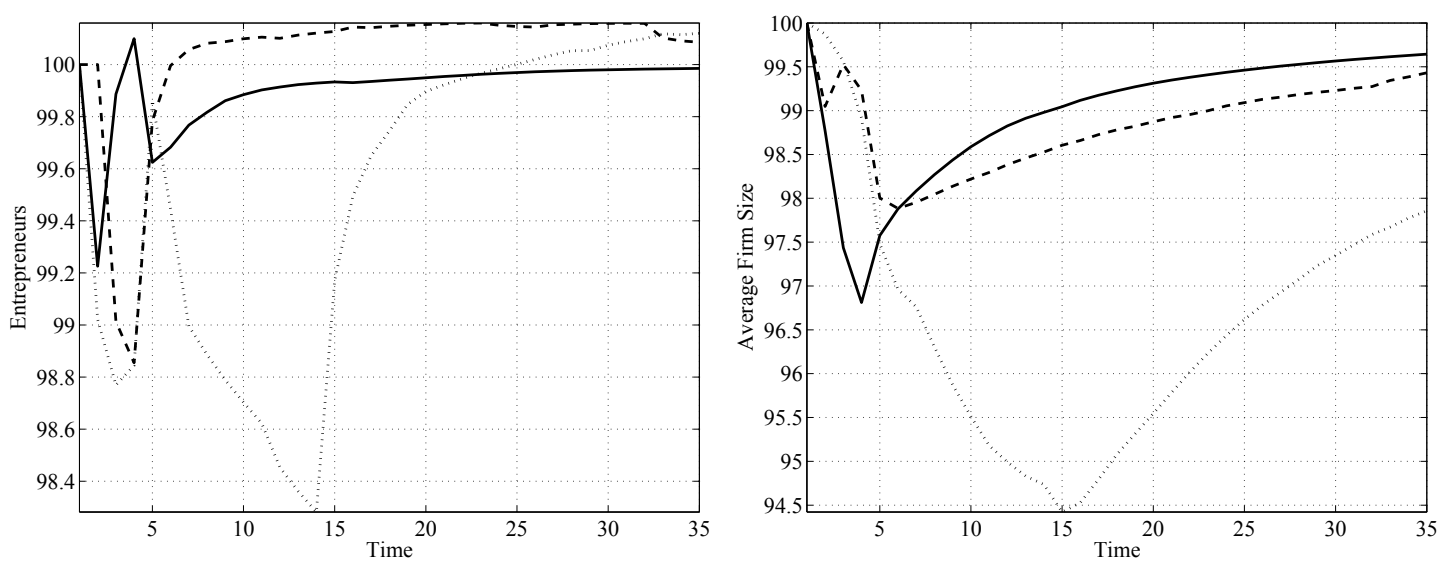

Figure 4: Number of entrepreneurs (left) and average size of entrepreneurial firms (right) in response to a shock to $\phi$. Steady state $=100$. Solid line: fixed lending rate, government spending adjusts. Dashed line: general equilibrium, government spending adjusts. Dotted line: general equilibrium, taxes adjust.

Figure 4 shows the effect of the financial intermediation shock on the number of entrepreneurs and their average firm size. The fraction of entrepreneurs drops, particularly when taxes adjust, but this margin is not very persistent: when intermediation costs and taxes are back to normal, entrepreneurs quickly reenter the market. This is because the minimum firm size that makes entry profitable is small, and potential entrepreneurs can save to reach that point quickly. Average firm size also drops; this effect is bigger and much more persistent. The intermediation cost reduces the entrepreneurs' cash flow and their ability to retain earnings to foster their business' growth. Since both the wealth distribution and the distribution of assets across firms that we match is very spread out, our model implies a very gradual growth of firms, with almost no entrepreneur attaining sufficient wealth that borrowing constraints cease to bind. It follows that any negative shock has almost a permanent effect on each entrepreneur, and its aggregate impact vanishes fully only when each entrepreneur loses his ability and closes the firm. As soon as the shock is over, firm growth resumes, but at a slow pace dictated by the tight borrowing limits.

The alternative ways in which taxes, spending, and interest rates adjust across the three experiments reveal some differences. Consider first the cases in which taxes are held fixed, and 


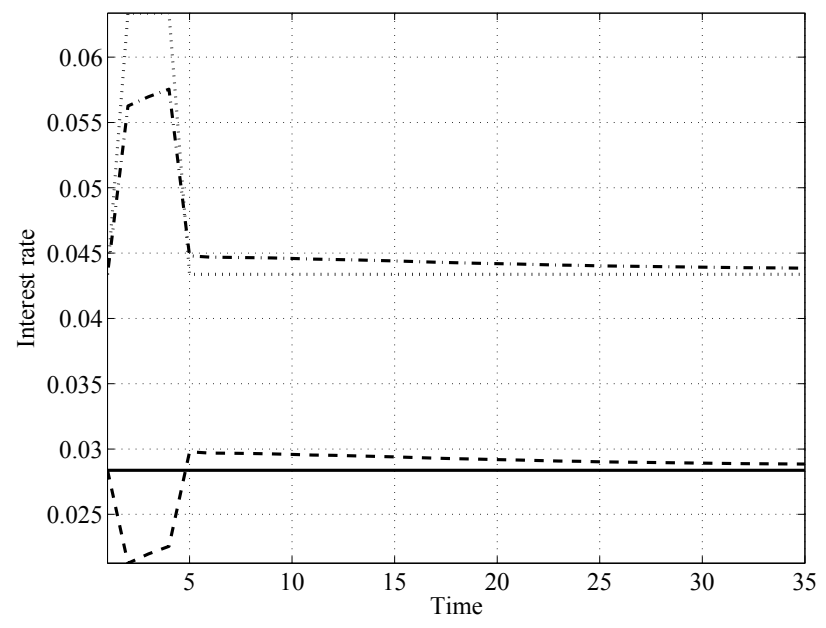

Figure 5: Evolution of interest rates in response to a shock to $\phi$ when government spending adjusts: experiment with a fixed lending rate ( solid $=$ lending rate, dotted $=$ borrowing rate) and general equilibrium (dashed = lending rate, dash-dotted = borrowing rate).

government spending acts as a residual. Figure 5 plots the borrowing and lending rates for the case in which the lending rate is held fixed (a small open economy) and that in which the capital market clears. During the periods of the shock, borrowing rates spike higher when savers have the opportunity of earning a fixed rate abroad. As a consequence, in Figure 4, average firm size drops more when lending rates are held constant (solid line) than when the effect of the shock is spread between borrowers and savers, as in general equilibrium (dashed line). The difference between partial and general equilibrium reverses after the shock is over. The shock triggers a reduction in aggregate capital; in general equilibrium, the resulting higher interest rates impair the entrepreneurs' ability to rebuild their balance sheet and lead to a slower recovery in firm size.

The differences between the solid and dashed lines in Figure 4 are minor compared to the differences between either of those lines and the dotted line, which represents the case in which the government balances its budget by increasing taxes rather than cutting government spending. To balance the budget, the government needs an increase in the tax rate of about $1.5 \%$ for 10 years. The government imbalance does not have a large impact on the depth of the initial recession, but it causes a prolonged slump once the fiscal adjustment takes place. Taxes deprive entrepreneurs 

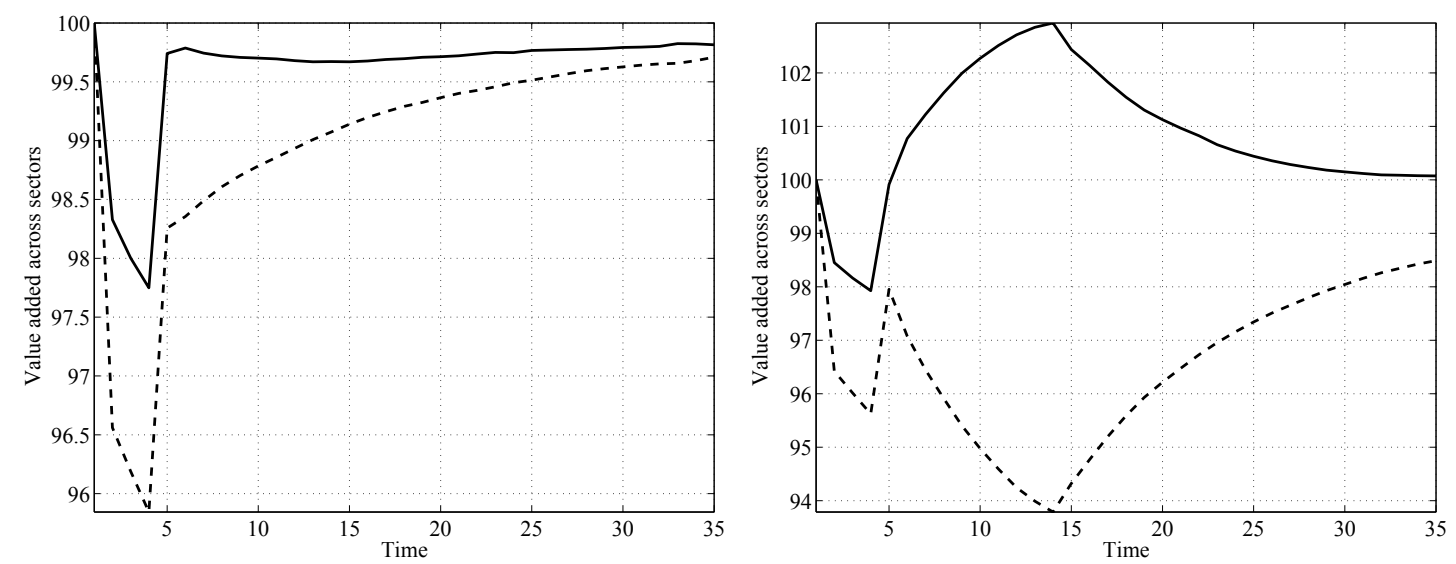

Figure 6: Value added in the corporate sector (solid) and entrepreneurial sector (dashed), in response to a shock to $\phi$. Left panel: general equilibrium with government spending adjusting. Right panel: general equilibrium with taxes adjusting. Steady state $=100$.

of resources to grow their firms, redistributing to government debt holders (workers), and they also drive a further wedge between savers and borrowers, since they hit capital as well as labor income. The tax increase is a new hit to the entrepreneurs' cash flow and results in a slow but persistent erosion of firm size, with a cumulative effect that is more than twice as large compared to the case of cuts in government spending. The recovery from the double shock of an increase in the intermediation cost and the subsequent response in taxes is thus delayed and starts from a weaker position.

Figure 6 compares value added in the entrepreneurial vs. the corporate sector of the economy. Since both sectors use capital intermediated by the financial sector, their value added drops when the cost of accessing the intermediaries' services increases. For our calibration, entrepreneurs are more reliant on financial intermediation, and the drop in their value added is twice as large than it is for the corporate sector. In period 5 the borrowing-cost shock is over and the effect reverses. In this period, the value added in the entrepreneurial sector grows faster than in the corporate sector; nonetheless, entrepreneurs do not recover fully, while the corporate sector stages a full recovery. The difference across the two sectors is due to the nature of the credit frictions faced by the two types of firms. Entrepreneurs are primarily constrained by their net worth, which can only 
be rebuilt slowly, whereas corporate firms curtail their investment only because of the additional cost of borrowing in equation (8), a period-by-period cost that returns almost to normal as soon as intermediation costs revert to their steady state level. From period 5, the behavior of the economy in the left and right panels of Figure 6 diverge. When (wasteful) government spending acts as the residual (left panel), no further shock perturbs the entrepreneurs' wealth accumulation, and the economy immediately starts on a path of slow convergence back to the steady state. In contrast, when taxes adjust, their effect on the entrepreneurs' balance sheet tightens the constraint on entrepreneurial firm size, and results in a reallocation of resources from entrepreneurs to corporate firms.

Due to computational limitations related to the endogenous borrowing constraints, our model features an inelastic labor supply, and thus it cannot capture the decline in labor occurring during the downturn. However, we can analyze the relative allocation of labor across the two sectors, which we show in Figure 7. This picture mirrors what we observed for output: the recession caused by the financial shock shrinks the share of employment at entrepreneurial firms, in line with Gertler and Gilchist's [21] observation that small firms are more sensitive to the business cycle. The share of employment at entrepreneurial firms stages a partial recovery when financial conditions return to normal, in period 5. From there, it continues on a path of gradual increase if government spending absorbs the impact of the shock on the government budget, whereas it drops anew and more markedly if taxes go up instead.

Having analyzed the forces that drive the behavior of our economy, we now turn to their aggregate implications. Figure 8 plots aggregate GDP. The increase in intermediation costs (an intermediate input in our economy) depresses TFP and output during the financial shock. This is particularly true when lending rates are fixed, since in this case capital moves out of the economy. ${ }^{11}$ In general equilibrium, the output drop on impact is mostly driven by the TFP effect of the shock: the drop in output is close to $3 \%$, with $0.3 \%$ being due to the misallocation of factors. As the net worth of entrepreneurs is eroded, the misallocation becomes a more prominent force; after the shock is over, the entire difference between the solid line and the steady state is

\footnotetext{
${ }^{11}$ National output declines much less, since the capital invested abroad continues to earn a rate of return.
} 


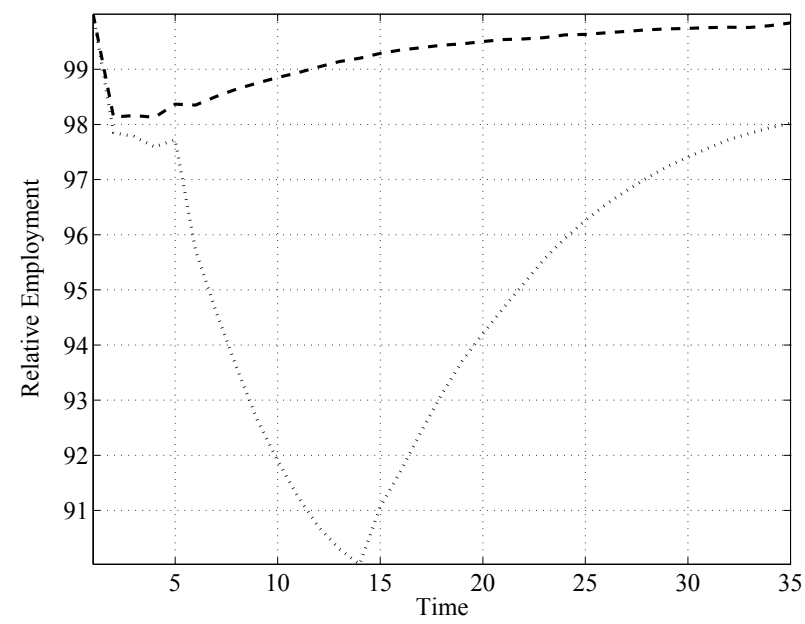

Figure 7: Employment in the entrepreneurial sector, relative to the corporate sector, in response to a shock to $\phi$. Dashed line: general equilibrium, government spending adjusts. Dotted line: general equilibrium, taxes adjust. Steady state $=100$.

due to this misallocation, whereas in general equilibrium (dashed and dotted line) the decrease in capital accumulation plays a role. When taxes hit the entrepreneurs' ability to accumulate wealth and grow their own business the economy fares much worse. This second dip would be less pronounced, the longer the transition period over which taxes are raised; but, of course, in this case the policy response to the shock would have even more persistent effects.

Figure 9 plots aggregate consumption and investment. ${ }^{12}$ As in most business-cycle models, investment bears the brunt of the shock on impact. Nonetheless, consumption drops too. Unlike a pure tightening of borrowing constraints, a shock to financial intermediation entails real output costs, that reduce total available resources from the outset. In general equilibrium, the behavior of aggregate investment contributes to a slow recovery: after the initial drop in the periods of the shock, investment never overshoots its steady-state level. When government spending adjusts,

\footnotetext{
${ }^{12}$ We do not plot aggregate investment for the case of fixed lending rates. In this case, the shock triggers a large capital outflow, and the drop in domestic investment happens on a much bigger scale, reversing itself after the intermediation shock is over. We do not view these international flows as realistic, but we are interested in this experiment purely as a way to isolate the effects of interest-rate movements on the economic incentives of the actors of our economy.
} 


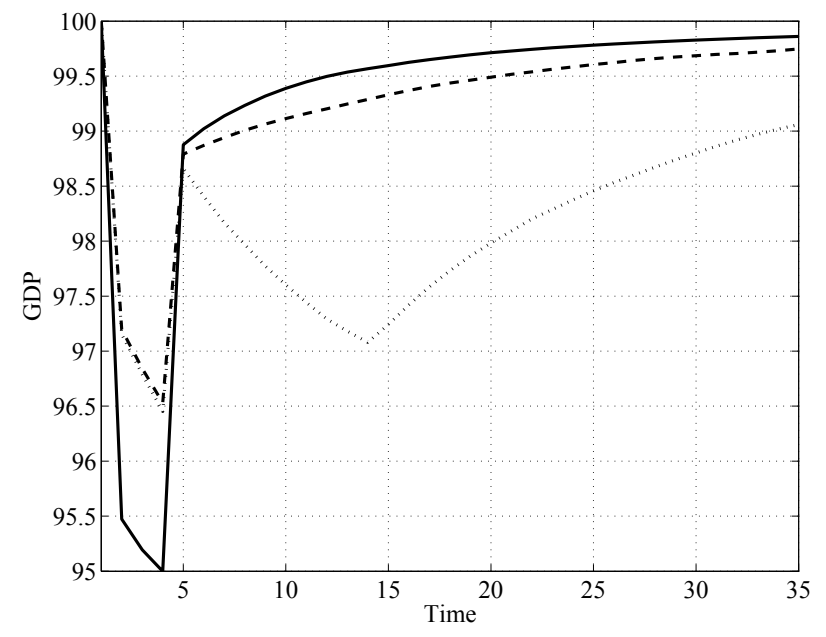

Figure 8: GDP in response to a shock to $\phi$. Solid line: fixed lending rate, government spending adjusts. Dashed line: general equilibrium, government spending adjusts. Dotted line: general equilibrium, taxes adjust. Steady state $=100$.

investment merely returns close to steady state; when taxes further depress wealth accumulation, investment remains $2 \%$ below its steady state several years after taxes have returned to their steady-state level.

It has often been remarked that, during the crisis, credit standards were extremely tight and that businesses found it difficult to access credit at any price (see for example the Quarterly Senior Loan Officer Opinion Survey conducted by the Federal Reserve Board). A similar effect arises in our model: the increase in intermediation costs is accompanied by an endogenous tightening of the constraints, because entrepreneurship becomes less profitable and thus the temptation of terminating the business and absconding part of the capital becomes stronger. To illustrate this mechanism, we run an alternative experiment, where intermediation costs increase by the same amount and duration ( $2 \%$ for three years), but borrowing constraints are held fixed exogenously at their steady-state values. Figure 10 compares the effect of the intermediation shock for exogenous and endogenous borrowing constraints, when the government spending acts as a residual. It shows that the adjustments of the extensive margin are almost exclusively driven by the tightening of the borrowing limits, that forces potential entrepreneurs to accumulate more 

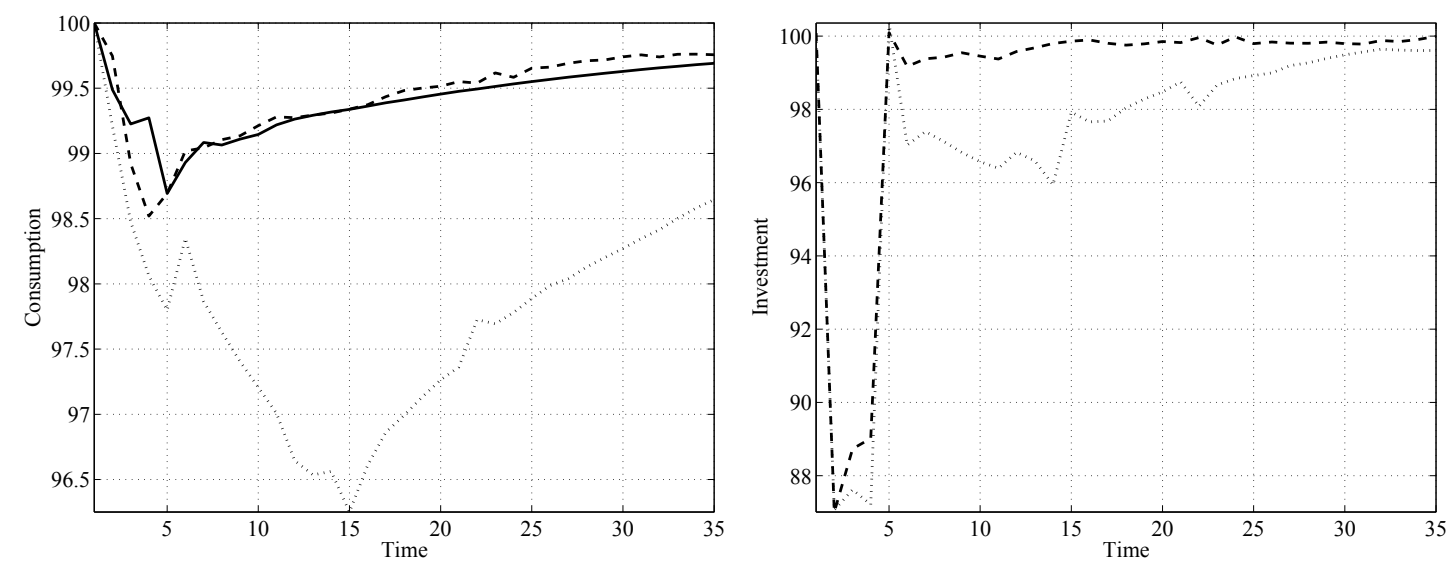

Figure 9: Aggregate consumption (left panel) and investment (right panel) in response to a shock to $\phi$. Solid line: fixed lending rate, government spending adjusts. Dashed line: general equilibrium, government spending adjusts. Dotted line: general equilibrium, taxes adjust. Steady state $=100$.

wealth before entry becomes worthwhile. The profit loss from the intermediation shock leads to smaller firms even with fixed borrowing constraints, but the drop in average firm size is about half as large. After the shock, the speed of recovery is similar, but the level from which the economy has to recover is much lower with endogenous borrowing constraints, so that it takes longer to return to the same level of output. The behavior of GDP with endogenous vs. fixed borrowing limits (Figure 11) mirrors the one for the average size of firms, but quantitatively the tightening of borrowing constraints has a more muted impact in the periods of the shock. When the shock is active, both entrepreneurs and corporate firms are subject to it, and holding borrowing limits fixed only benefits entrepreneurs. After the shock is over, the gap between the two lines widens, because the persistent effect of the shock is dictated by the evolution of entrepreneurial wealth, which is less severely impacted when borrowing constraints are held fixed.

Figures 12 and 13 compares the behavior of entrepreneurial firms and GDP with endogenous vs. fixed borrowing constraints in the case in which the government raises taxes to balance its budget. The differences are here starker, because an increase in taxes drains the profitability of entrepreneurs and generates its own credit crunch if borrowing constraints are allowed to adjust 

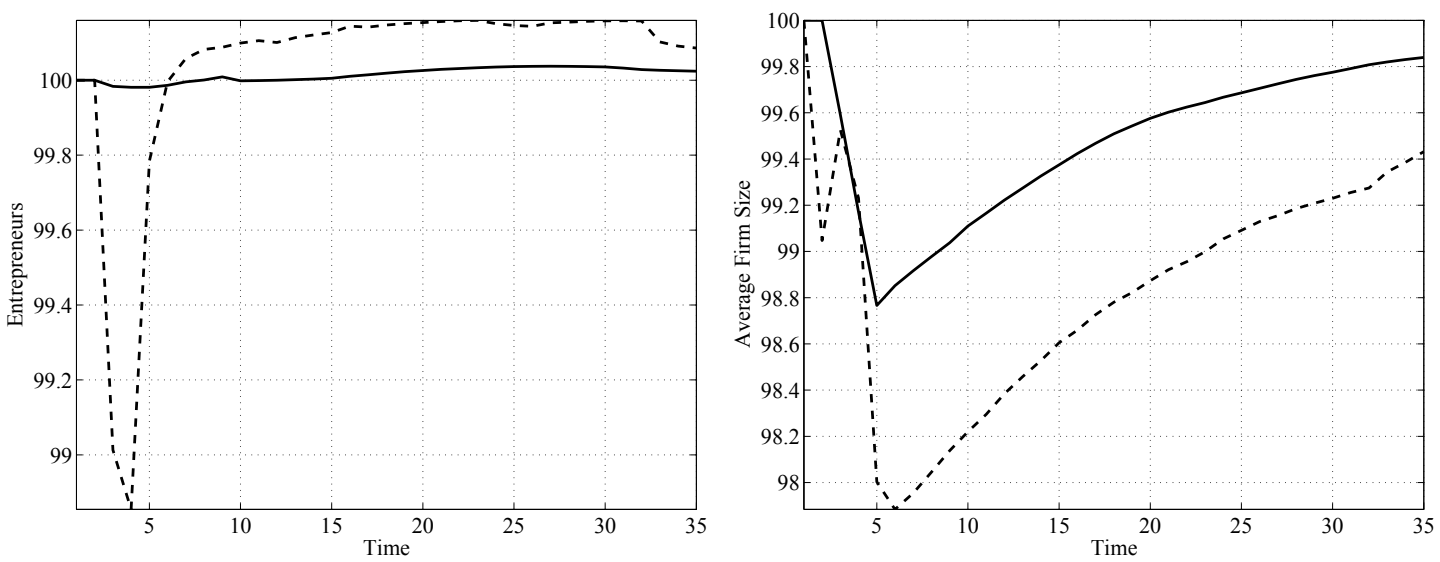

Figure 10: Number of entrepreneurs (left) and average size of entrepreneurial firms (right) in response to a shock to $\phi$ with borrowing constraints held fixed (solid line) and allowed to vary endogenously (dashed line). Steady state $=100$. General equilibrium, government spending adjusts.

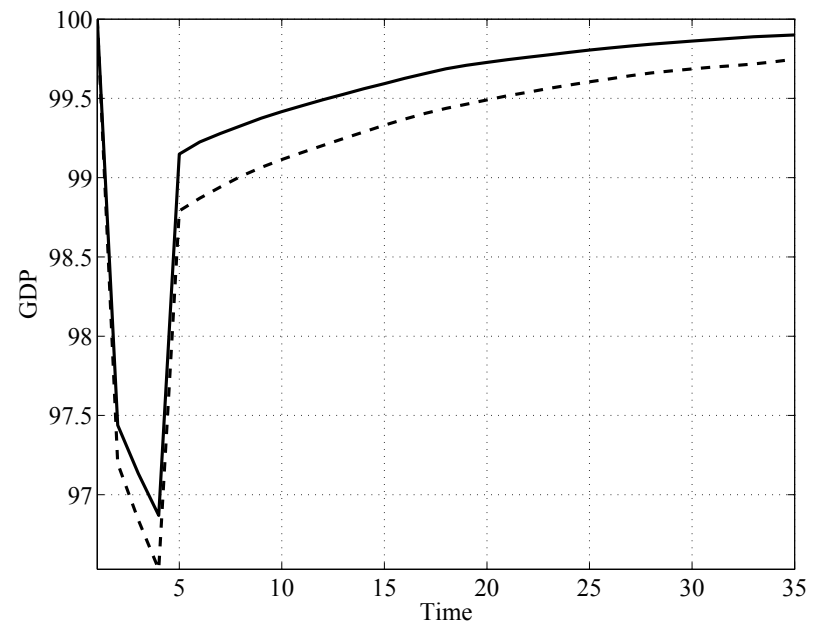

Figure 11: GDP in response to a shock to $\phi$ with borrowing constraints held fixed (solid line) and allowed to vary endogenously (dashed line). Steady state $=100$. General equilibrium, government spending adjusts. 

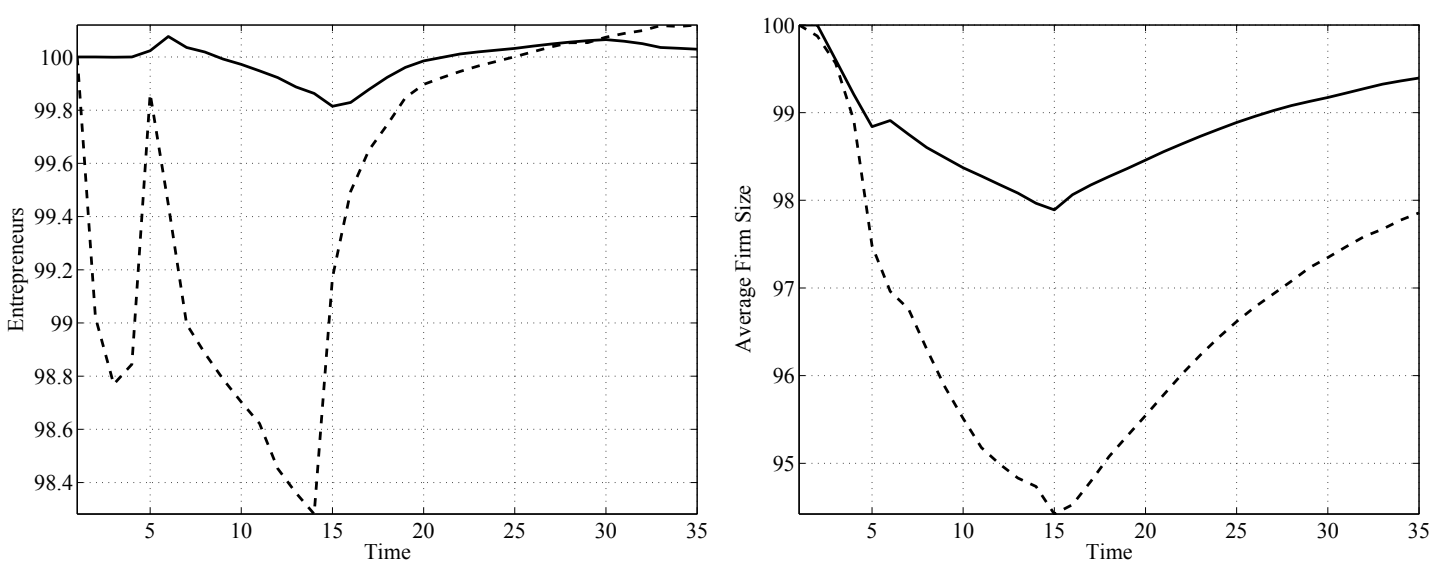

Figure 12: Number of entrepreneurs (left) and average size of entrepreneurial firms (right) in response to a shock to $\phi$ with borrowing constraints held fixed (solid line) and allowed to vary endogenously (dashed line). Steady state $=100$. General equilibrium, taxes adjust.

endogenously.

\subsection{Negative technology shock in the intermediation sector, only for entrepreneurs.}

In the wake of the financial crisis of 2008, the government took several actions aimed at restoring calm in several financial markets. Among the actions that were most successful ex-post was a blanket guarantee of money-market mutual funds, and thus, indirectly, of the commercial paper of corporate industrial firms that those funds purchased. More in general, companies with direct access to markets seemed better able to cope than those that were forced to go through the banking sector. ${ }^{13}$

In this section, we consider the same shock to $\phi$ as in the previous section, but we assume that the government neutralizes its impact on the corporate sector; we do so by varying $\xi_{t}$ to hold $\xi_{t} \phi_{t}$ constant throughout. We take the best-case scenario in which this policy comes at no

\footnotetext{
${ }^{13}$ For instance, data from the Flow of Fund s accounts show that bond issuance for large corporations recovered quickly after the financial crisis, while bank lending remained subdued for several years.
} 


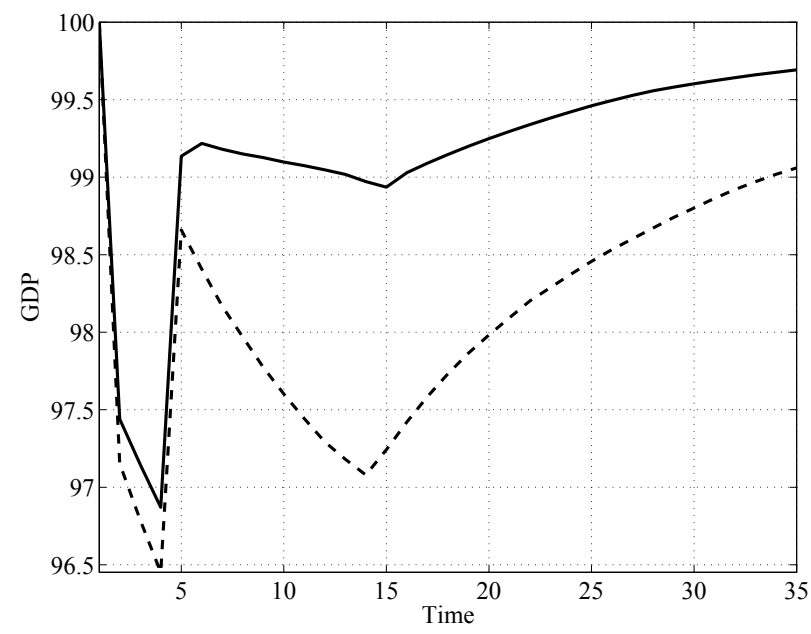

Figure 13: GDP in response to a shock to $\phi$ with borrowing constraints held fixed (solid line) and allowed to vary endogenously (dashed line). Steady state $=100$. General equilibrium, taxes adjust.

cost, in the way this happened with the money market guarantee ex-post. ${ }^{14}$

Figure 14 studies the differences between this experiment and the case of a pure shock to $\phi$ for the entrepreneurial sector, in the case of general equilibrium and fixed taxes (with government spending adjusting as a residual). Since corporate firms are insulated from the shock in this new experiment, entrepreneurs face stiffer competition in the factor markets, which thins their ranks and leads them to shrink their firm size more. The recovery is affected by two opposite forces. The greater hit taken by entrepreneurs slows the return to the steady state. However, aggregate investment (Figure 15) drops less when only one sector is hit by the shock, and the additional capital is beneficial to the recovery. The first force dominates in the short run, but about 5 years after the shock the two experiments become quite similar.

Figure 16 displays the value added in the two sectors in response to the shock to $\phi$ and the contemporaneous offset through $\xi$. When the corporate sector is completely insulated, its size actually expands during the financial disruption, as it poaches workers and capital from the

\footnotetext{
${ }^{14}$ We could easily add a cost to this guarantee, in which case taxes would have to go up more during the transition, and would exacerbate the persistence of the drop in output.
} 

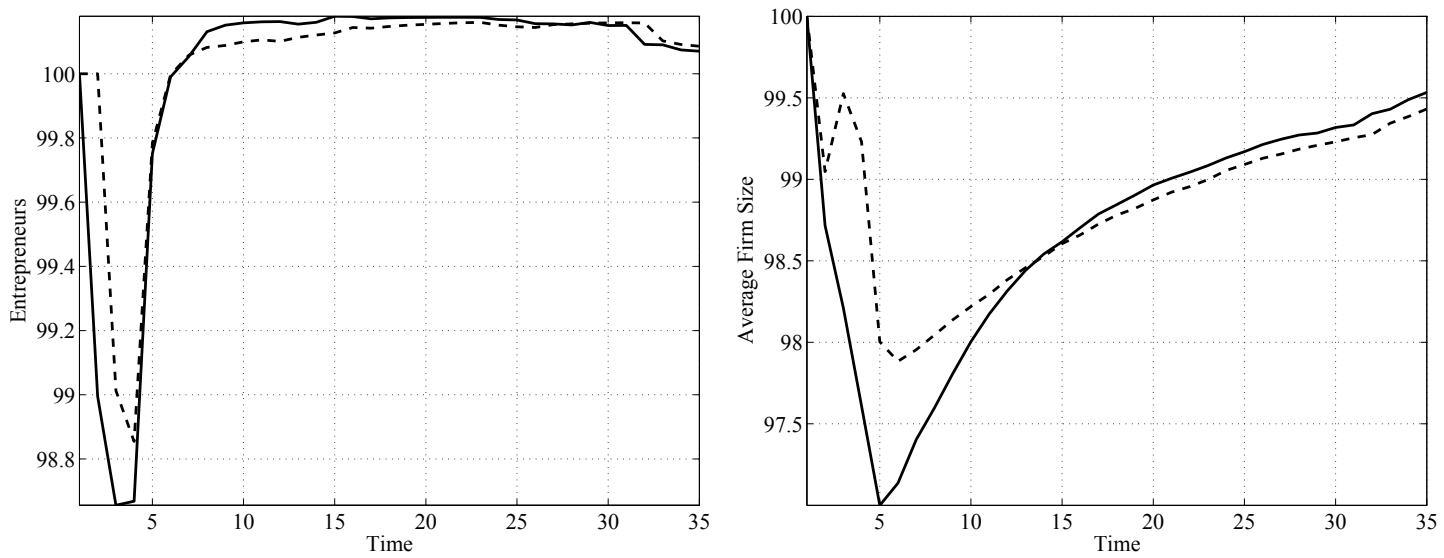

Figure 14: Number of entrepreneurs (left) and average size of entrepreneurial firms (right) in response to a shock to $\phi$ (solid line), and to $\phi$ and $\xi$ simultaneously (dashed line). Steady state $=100$. General equilibrium, government spending adjusts.

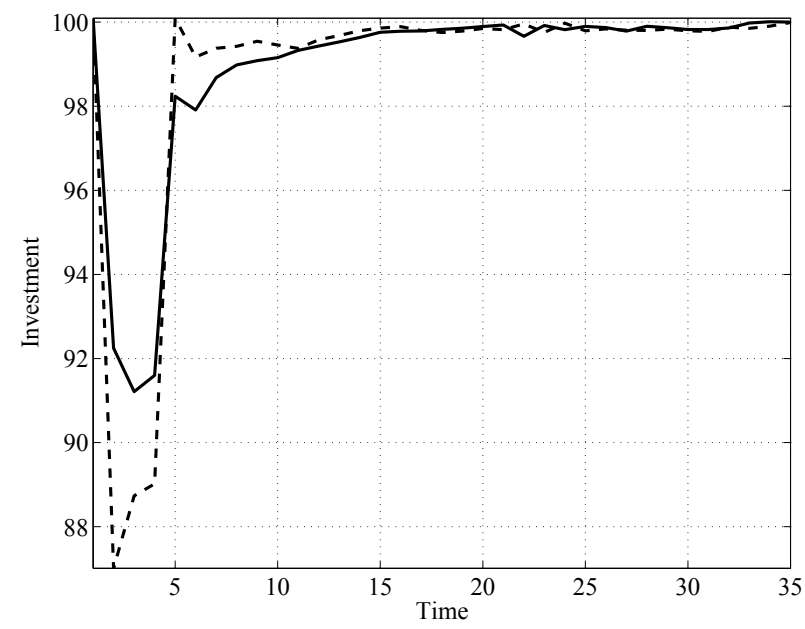

Figure 15: Aggregate investment in response to a shock to $\phi$ (solid line), and to $\phi$ and $\xi$ simultaneously (dashed line). Steady state $=100$. General equilibrium, government spending adjusts. 


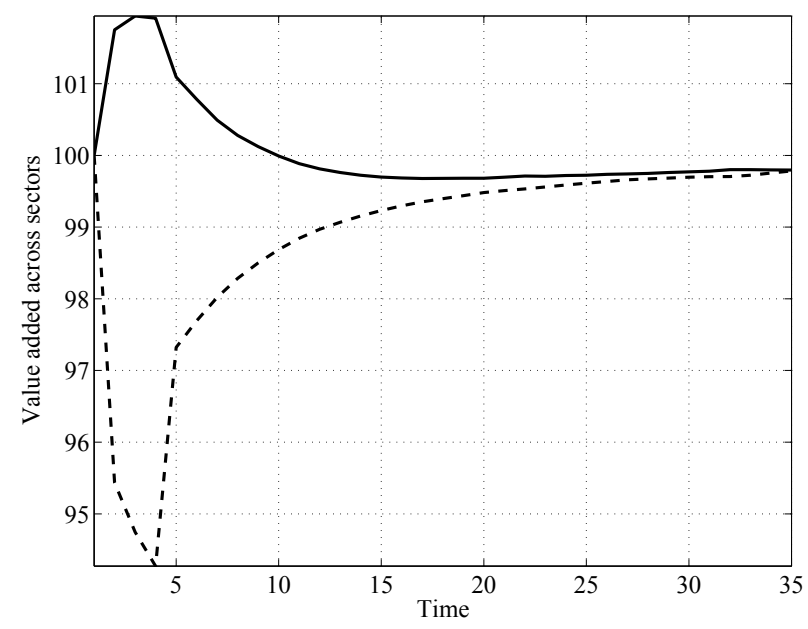

Figure 16: Value added in the corporate sector (solid) and entrepreneurial sector (dashed), in response to a shock to $\phi$ and $\xi$ simultaneously. General equilibrium with government spending adjusting.

entrepreneurs.

Figure 17 shows how all of these effects combine to determine aggregate GDP. Even in the best-case scenario in which the government intervention entails no cost, it is successful at reducing the severity of the recession, but it has almost no impact on the recovery. By helping the corporate sector, the government exacerbates the misallocation of resources due to financial frictions.

\subsection{A shock to required collateral.}

Here, we consider a shock that increases the collateral that the entrepreneurs need to secure their loans. Specifically, we raise the fraction of capital than can be absconded $(f)$ from $75 \%$ to $80 \%$. We calibrate this shock to have an effect on aggregate output during the credit crunch that is of similar magnitude of the drop that we obtained considering a shock to $\phi$, for the cases of general equilibrium. This can be seen in Figure $18 .^{15}$

\footnotetext{
${ }^{15}$ For brevity, we present only the case in which government spending adjusts to restore budget balance. The conclusions that we draw for this case apply also to the case in which taxes adjust instead.
} 


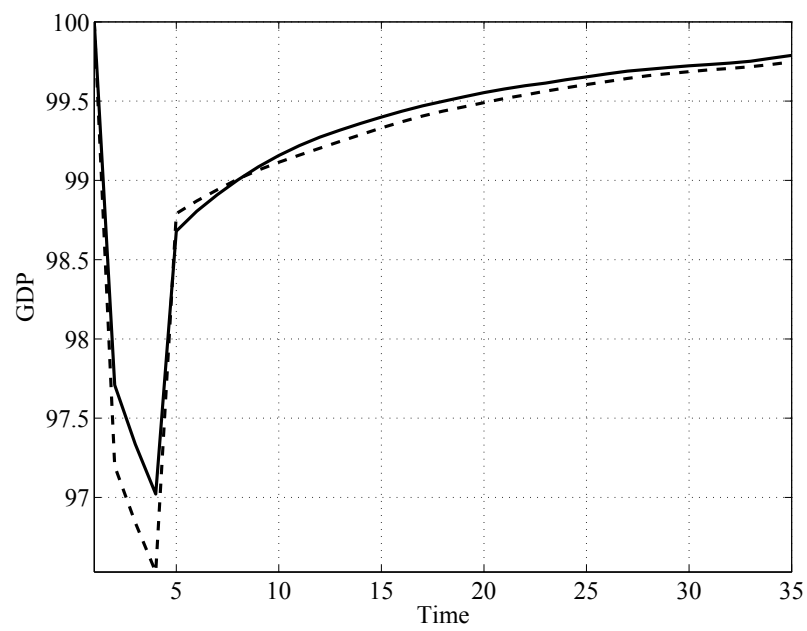

Figure 17: GDP in response to a shock to $\phi$ (solid line), and to $\phi$ and $\xi$ simultaneously (dashed line). Steady state $=100$. General equilibrium, government spending adjusts.

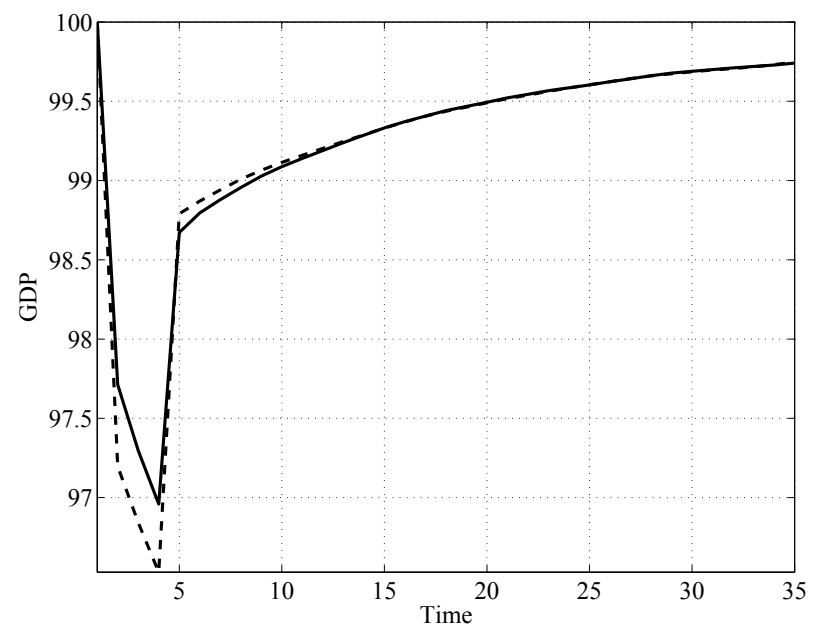

Figure 18: GDP in response to a shock to $f$ (solid line) and $\phi$ (dashed line). Steady state $=100$. General equilibrium, government spending adjusts. 

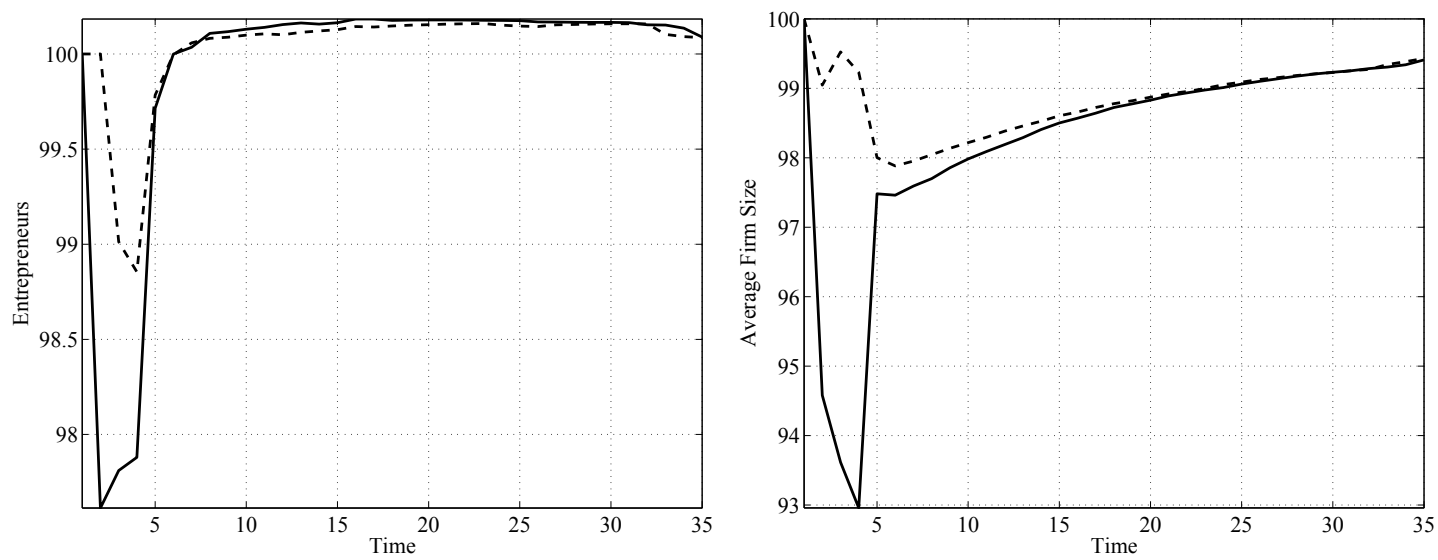

Figure 19: Number of entrepreneurs (left) and average size of entrepreneurial firms (right) in response to a shock to $f$ (solid line) and $\phi$ (dashed line). Steady state $=100$. General equilibrium, government spending adjusts.

Since this shock only affects the entrepreneurial sector, matching the output drop in impact requires a much deeper contraction in the number of entrepreneurs and firm size when $f$ increases than the baseline case in which borrowing costs increase for both entrepreneurs and corporate firms. This can be seen in Figure 19. It might seem surprising that the deeper contraction in entrepreneurial firms does not bear bigger implications for the entrepreneurs wealth in the recovery phase. The reason for this result is that a shock to $f$ hits only the marginal profits of the firm: it forces entrepreneurs to shrink their scale, but it has no effect on their profits for a given scale of operations. In contrast, an increase in $\phi$ raises the rental rate of capital paid by entrepreneurs; this effect applies to all of the capital that they rent, and has a negative effect on their profits even conditioning on their scale of operations.

\subsection{A TFP shock.}

We finally contrast a credit shock to a TFP shock that hits both the corporate sector and the entrepreneurial sector. In this case, total factor productivity drops by $2.5 \%$ for 3 years, and subsequently reverts to steady state. Once again, the magnitude of the TFP drop is chosen so as to obtain a similar GDP drop on impact in general equilibrium. As Figures 20 and 21 show, 


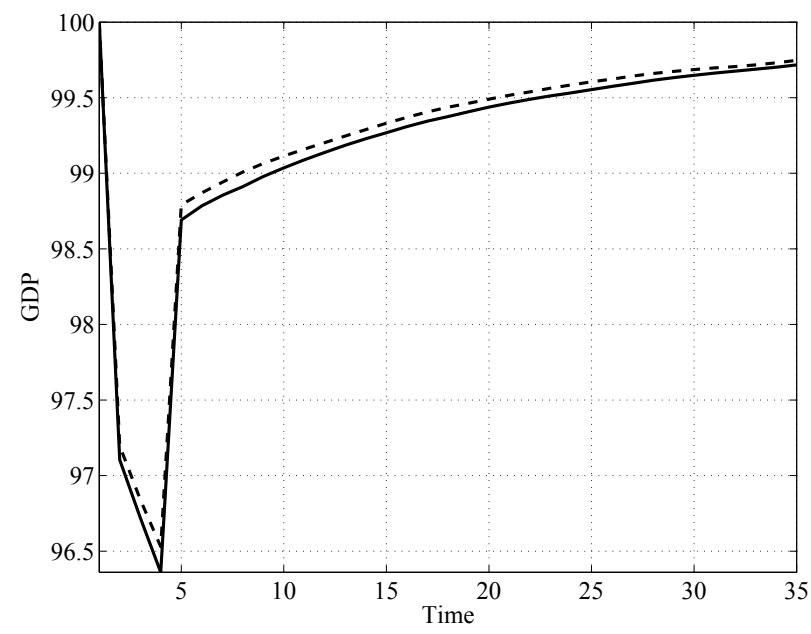

Figure 20: GDP in response to a shock to TFP (solid line) and $\phi$ (dashed line). Steady state $=$ 100. General equilibrium, government spending adjusts.

the evolution of the economy under this shock is fairly similar to that of a shock to $\phi$.

\section{Conclusion}

From the experiments that we ran, we learn three lessons. First, and foremost, we find that it is not the source of the disturbance that determines our economy's speed of recovery, but rather the way in which the shock affects the profitability of credit-constrained entrepreneurs. Recovery is comparatively slowest in the case of an increase in borrowing rates from which the corporate sector is shielded (our experiment of Section 6.2). Among our experiments, this one has the shallowest recession, and yet during the recovery output is at a similar level as that of the others, in which the economy needs to make up for deeper drops. When losses are concentrated in the entrepreneurial sector, it takes more time for entrepreneurs to rebuild their balance sheet.

Second, the way public finances adjust in response to the shortfalls caused by a recession is important. Income taxes are a further drain on the cash flow available for successful business owners to grow and represent a further significant drag on the economy. From an efficiency perspective, entrepreneurship subsidies would contribute to increase output. It should be noted that 

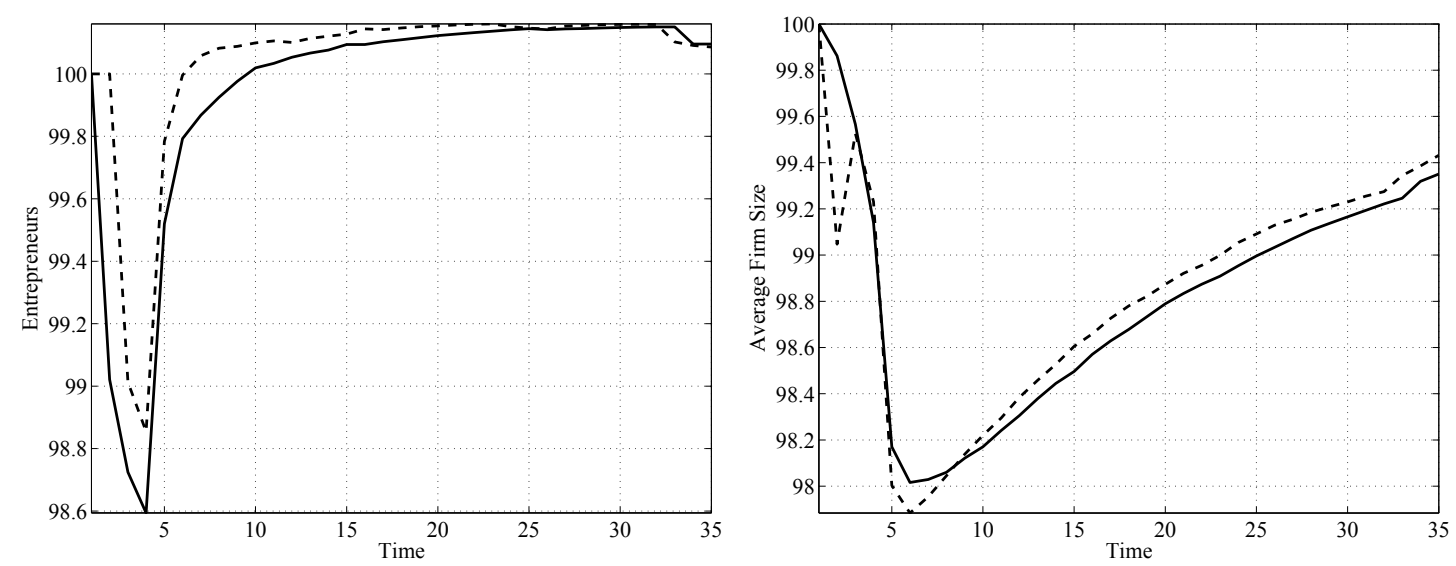

Figure 21: Number of entrepreneurs (left) and average size of entrepreneurial firms (right) in response to a shock to $\mathrm{TFP}$ (solid line) and $\phi$ (dashed line). Steady state $=100$. General equilibrium, government spending adjusts.

this does not necessarily imply that subsidizing entrepreneurs is an optimal policy. Even if it were easy to identify the exact counterpart to credit-constrained, highly productive entrepreneurs, this policy would require taxing workers, who are on average far poorer in our economy, as in the data, to subsidize comparatively richer business owners, raising equity considerations.

Finally, in an environment with endogenous borrowing constraints, financial shocks that increase interest costs have two effects. The interest rate increase represents a direct drain on firms' profits. The indirect effect is that higher borrowing rates trigger a tightening of credit limits. Hence, for a given contraction in credit, financial shocks that affect borrowing rates have potentially more severe implications than pure credit rationing.

\section{References}

[1] Tobias Adrian and Hyun Song Shin. Financial Intermediation and Monetary Economics. Staff Report 398, Federal Reserve Bank of New York, Oct 2009.

[2] Rui Albuquerque and Hugo A. Hopenhayn. Optimal Dynamic Lending Contracts with Imperfect Enforceability. Review of Economic Studies, 71(2):285-315, Apr 2004. 
[3] David Altig, Alan J. Auerbach, Laurence J. Kotlikoff, Kent A. Smetters, and Jan Walliser. Simulating Fundamental Tax Reform in the United States. American Economic Review, 91(3):574-595, June 2001.

[4] David Altig, Alan J. Auerbach, Laurence J. Kotlikoff, Kent A. Smetters, and Jan Walliser. Simulating Fundamental Tax Reform in the United States. American Economic Review, 91(3):574-595, June 2001.

[5] Fernando Alvarez and Urban Jermann. Efficiency, Equilibrium, and Asset Pricing with Risk of Default. Econometrica, 68(4):775-797, 2000.

[6] Kartik Athreya and Ahmet Akyol. Self-Employment Rates and Business Size: The Roles of Occupational Choice and Credit Market Frictions. Annals of Finance, 5(3-4):495-519, Jun 2009.

[7] Orazio P. Attanasio, James Banks, Costas Meghir, and Guglielmo Weber. Humps and Bumps in Lifetime Consumption. Journal of Business and Economic Statistics, 17(1):2235, January 1999.

[8] Ben S. Bernanke and Mark Gertler. Agency Costs, Net Worth, and Business Fluctuations. American Economic Review, 79(1):14-31, Mar 1989.

[9] Ben S. Bernanke, Mark Gertler, and Simon Gilchrist. The Financial Accelerator in a Quantitative Business Cycle Framework. In John Taylor and Michael Woodford, editors, Handbook of Macroeconomics, volume 1C, pages 1341-1393. Elsevier, 1999.

[10] Markus Brunnermeier and Yuliy Sannikov. A Macroeconomic Model with a Financial Sector. Mimeo, Princeton University, 2010.

[11] Francisco Buera. A Dynamic Model of Entrepreneurship with Borrowing Constraints: Theory and Evidence. Annals of Finance, 5(3-4):443-464, Jun 2009.

[12] Francisco Buera and Yongseok Shin. Financial Frictions and the Persistence of History: A Quantitative Exploration. Mimeo, UCLA. 
[13] Marco Cagetti and Mariacristina De Nardi. Entrepreneurship, Frictions, and Wealth. Journal of Political Economy, 114(5):835-870, October 2006.

[14] Marco Cagetti and Mariacristina De Nardi. Estate Taxation, Entrepreneurship, and Wealth. American Economic Review, 99(1):85-111, 2009.

[15] Ana Castañeda, Javier Díaz-Giménez, and José-Victor Ríos-Rull. Accounting for the U.S. Earnings and Wealth Inequality. Journal of Political Economy, 111(4):818-857, Aug 2003.

[16] Lawrence Christiano, Roberto Motto, and Massimo Rostagno. Financial Factors in Economic Fluctuations. Working Paper 1192, European Central Bank, May 2010.

[17] Thomas Cooley, Ramon Marimon, and Vincenzo Quadrini. Aggregate Consequences of Limited Contract Enforceability. Journal of Political Economy, 112(4):817-847, Aug 2004.

[18] Francisco Covas and Shigeru Fujita. Private Risk Premium and Aggregate Uncertainty in the Model of Uninsurable Investment Risk. Working Paper 07-30, Federal Reserve Bank of Philadelphia, 2007.

[19] Vasco Curdia and Michael Woodford. Credit Spreads and Monetary Policy. Staff Report 385, Federal Reserve Bank of New York, Aug 2009.

[20] Mariacristina De Nardi. Wealth Inequality and Intergenerational Links. Review of Economic Studies, 71(3):743-768, July 2004.

[21] Mark Gertler and Simon Gilchrist. Monetary Policy, Business Cycles, and the Behaviour of Small Manufacturing Firms. The QuarterLy Journal of Economics, 109(2):309-340, 1994.

[22] Mark Gertler and Nobuhiro Kiyotaki. Financial Intermediation and Credit Policy in Business Cycle Analysis. In Benjamin M. Friedman and Michael Woodford, editors, Handbook of Monetary Economics. Elsevier, Forthcoming.

[23] Simon Gilchrist, Jae Sim, and Egon Zakrajsek. Uncertainty, Financial Frictions, and Investment Dynamics. Mimeo, Boston University, 2010. 
[24] Douglas Gollin. Getting Income Shares Right. Journal of Political Economy, 110(2):458474, April 2002.

[25] Miguel Gouveia and Robert P. Strauss. Effective Federal Individual Income Tax Functions: An Exploratory Empirical Analysis. National Tax Journal, 47(2):317-339, June 1994.

[26] Robert E. Hall. The High Sensitivity of Economic Activity to Financial Frictions. Mimeo, Stanford University, 2009.

[27] John Heaton and Deborah Lucas. Portfolio Choice and Asset Prices: The Importance of Entrepreneurial Risk. Journal of Finance, 55(3):1163-1198, Jun 2000.

[28] Mark Huggett. Wealth Distribution in Life-cycle Economies. Journal of Monetary Economics, 38(3):469-494, December 1996.

[29] Urban Jermann and Vincenzo Quadrini. Macroeconomic Effects of Financial Shocks. Discussion Paper 7451, CEPR, 2009.

[30] Urban J. Jermann and Vincenzo Quadrini. Stock market boom and the productivity gains of the 1990s. Journal of Monetary Economics, 54(2):413-432, 2007.

[31] Timothy J. Kehoe and David K. Levine. Debt-constrained Asset Markets. Review of Economic Studies, 60(4):865-888, October 1993.

[32] Aubhik Khan and Julia Thomas. Credit Shocks and Aggregate Fluctuations in an Economy with Production Heterogeneity. Mimeo, Ohio State University, 2011.

[33] Sagiri Kitao. Entrepreneurship, Taxation, and Capital Investment. Review of Economic Dynamics, 11(1):44-69, Jan 2008.

[34] Nobuhiro Kiyotaki and John Moore. Credit Cycles. Journal of Political Economy, 105(2):211-248, Apr 1997. 
[35] Laurence J. Kotlikoff, Kent A. Smetters, and Jan Walliser. Privatizing Social Security in the United States: Comparing the Options. Review of Economic Dynamics, 2(3):532-574, July 1999 .

[36] Arvind Krishnamurthy. Amplification Mechanisms in Liquidity Crises. American Economic Journal: Macroeconomics, Forthcoming 2010.

[37] Arvind Krishnamurthy and Annette Vissing-Jorgensen. The Demand for Treasury Debt. Working Paper 12881, NBER, 2007.

[38] Lee A. Lillard and Robert J. Willis. Dynamic Aspects of Earning Mobility. Econometrica, 46(5):985-1012, September 1978.

[39] Robert E. Lucas, Jr. On the Size Distribution of Business Firms. The Bell Journal of Economics, 9(2):508-523, 1978.

[40] Césaire Meh. Entrepreneurship, Wealth Inequality, and Taxation. Review of Economic Dynamics, 8(3):688-719, Jul 2005.

[41] Alexander Monge. Entrepreneurship and Firm Heterogeneity under Limited Commitment. Annals of Finance, 5(3-4):465-494, 2009.

[42] Vincenzo Quadrini. The Importance of Entrepreneurship for Wealth Concentration and Mobility. Review of Income and Wealth, 45(1):1-19, Mar 1999.

[43] Vincenzo Quadrini. Entrepreneurship, Saving, and Social Mobility. Review of Economic Dynamics, 3(1):1-40, 2000.

[44] Vincenzo Quadrini and José-Victor Ríos-Rull. Models of the Distribution of Wealth. Federal Reserve Bank of Minneapolis Quarterly Review, 21(2):1-21, Spring 1997.

[45] Nikolai Roussanov. Diversification and Its Discontents: Idiosyncratic and Entrepreneurial Risk in the Quest for Social Status. Journal of Finance, Forthcoming 2010. 
[46] Nancy L. Stokey and Sergio Rebelo. Growth Effects of Flat-Rate Taxes. Journal of Political Economy, 103(3):519-550, June 1995.

[47] George Tauchen and Robert Hussey. Quadrature-Based Methods for Obtaining Approximate Solutions to Nonlinear Asset Pricing Models. Econometrica, 59(2):371-396, March 1991. 